\title{
Pollutant Removal from Sewage in Tropical Climate by Constructed Wetland System: An Asset for Irrigation
}

\author{
Boopathy Usharani ${ }^{1, \mathrm{a}^{*}}$ and Namasivayam Vasudevan ${ }^{2}$ \\ 1Department of Biochemistry, VISTAS, Chennai 600117 \\ ${ }^{2}$ Centre for Environmental Studies, Anna University, Chennai 600025 \\ *raniushab1@gmail.com
}

\begin{abstract}
Keywords: Constructed wetland system; Cyperus alternifolius; HLR; Kinetics performance;
\end{abstract} pollutant; removal; Removal efficiency (\%).

\begin{abstract}
In the global outlook, letting of untreated sewage in existing river bodies deteriorates the water quality. The seepage likely depreciates the quality of ground water too. The quality of groundwater with special reference to India has tremendously gone down in the past twenty years leading to sour taste. On the other hand, agriculture sector is deprived of water in many places of India. A solution can be arrived concurrently by treating sewage and consuming the effluent in agricultural sector. First order kinetics was applied in constructed wetland system at different flow rates and optimised. At optimised HLR, effluent met the standards of discharge that can be utilized for agricultural/ irrigational purpose. The emanating major pollutants can be effectively treated using constructed wetland system under tropical climate. A few clippings at the onsite treatment illustrated the diversity of species thus adjoining sustainable biodiversity and treatment. Thus in tropical countries like India, constructed wetland system might pave solution not only for the treatment of sewage but in deploying the effluent in agricultural sector. A clean ecosystem can be achieved with sustainability.
\end{abstract}

\section{Introduction}

Wastewater discharge from diverse sector releases a wide range of contaminants seeking profound attention of the environmentalists worldwide. Organic pollution of the rivers have a serious negative impact on human health and ecosystem. In the Indian scenario, about 62,000 MLD of domestic wastewater (sewage) is generated while the treatment capacity is only $37 \%$ of it. Remaining $63 \%$ of untreated sewage is let into rivers across the country including the Ganga River basin which supports almost $45 \%$ of living population (Times of India 2015). Agriculture being the backbone of the country strives due to water depletion. Henceforth, providing an effective solution correlating with environmental concern is focussed.

The sources that contribute to contamination of water bodies are bounteous and majorly anthropogenic. The River Yamuna in Delhi, India is highly polluted by domestic wastewater with elevated levels of ammonium concentration making it unfit for human consumption (Groeschke et al. 2017). Water quality of the upstream and downstream of the River Mandzoro was studied and reported by Baloyi et al. (2014) that there was deterioration in the water quality at the downstream due to the discharge of poor quality effluent from the sewage treatment plant. Indirect source of contamination may be due to urbanization, seepage of storm water, agricultural run-off and precipitation of atmospheric contaminants released owing to industrial evolution (Naderizadeh et al. 2016).

\subsection{List of pollutants in domestic wastewater}

The major pollutants in domestic wastewater that deteriorates the water quality when released in water bodies are cited. 


\subsubsection{Organic pollutants}

The organic pollutants emanate majorly from domestic sewage, storm water, industrial effluent and agricultural run-off. Decomposition of organic pollutants results in the depletion of oxygen thus deeming it unfit for the survival of biotic life (Sharma \& Gupta 2014). The organic pollutants from wastewater discharges had seriously affected the macro invertebrates in aquatic system. Globally the number of people affected by organic pollution of (Biological Oxygen Demand) $\mathrm{BOD}>5 \mathrm{mg} / \mathrm{L}$ due to contamination of rivers was projected to be 2.5 billion in 2015 (Wen et al. 2017).

\subsubsection{Nutrients}

The major nutrients such as phosphorus and nitrogen are released in disagreeable amounts in domestic wastewater. The bounteous supply of nutrient leads to eutrophication. Excess nitrogen results in toxic algal blooms that gains entry via food chain and poses threat to aquatic life and humans leading to economic loss (Naden et al. 2016).

\subsubsection{Heavy metals}

Domestic wastewater contains heavy metals zinc, iron, cadmium, copper, aluminium, lead and manganese. A study conducted in Japan revealed that an average of $0.2-0.3 \mathrm{Cd}, 1.6-1.9 \mathrm{Ni}, 3.5-$ 6.8 Pb, 0.8-1.4 Cr, 8.2-19.3 Mn, 9.4- 55.8 Cu, 44.3-62.7 $\mathrm{Zn}$ and 111- $293 \mathrm{Fe} \mathrm{mg/} \mathrm{day/} \mathrm{person} \mathrm{is}$ released in domestic wastewater. Intrusion of sewage contamination has led to heavy metal concentration of lead, chromium, cadmium and nickel in underground water, surface water, soil and crop plants (Chino et al. 1991). The sources of heavy metal contamination in sewage are rainfall and soil erosion. These heavy metal containing aerosols usually accumulate on leaf surfaces in the form of fine particulates and can enter the leaves via stomata. Some of the human sources of heavy metals in wastewater effluents are metal finishing and electroplating, mining and extraction operations, textiles activities and nuclear power. Metal finishing and electroplating involve the deposition of thin protective layers into prepared surfaces of metal using electrochemical processes (Oghenerobor et al 2014)

\subsubsection{Microbial contamination}

Most of the rivers are polluted with fecal indicators such as total coliform, fecal coliform, Escherichia coli and fecal Streptococci due to contamination of excreta by humans and warm blooded animals. A study conducted in the rural sectors of Odisha, India by Schriewer et al. (2015) revealed human fecal markers in community water resources such as ponds $(8 \%)$, tube wells $(2 \%)$ and stored water $(20 \%)$.

Bacterial analysis of River Ganges revealed that it is highly contaminated with coliforms, Enterococcus faecalis, Actinomyces sp., Aerobacter aerogenes Staphylococcus aureus, Shigella sp., Bacillus sp., Salmonella sp. and Clostridium perfringens. Hence consumption of Ganga water may lead to serious health risks (Bilgrami \& Kumar 1998). Coliform infection, especially E. coli causes bloody diarrhea, nausea, vomiting, dehydration, fever and loss of appetite.

\subsubsection{Emerging pollutants}

Major emerging pollutants like carbamazepine, galaxolide and tonalide arise from pharmaceutical and cosmetic usage. Antibiotics sulfamethoxazole in wastewater is persistent and monitoring of wastewater for emerging pollutants is essential (Lamastra et al. 2016).

\subsection{Essence of CWS in India}

Water deficit is prevalent due to depletion of groundwater table. In India, agricultural sector consumes $82 \%$ of the total water supply. Hence, domestic wastewater can be treated and reused for agricultural purpose instead of letting it into water bodies thereby preserving its aesthetic value. Though many technologies are available, constructed wetland system (CWS) is the best ever green technology with less maintenance and operation cost to treat wastewaters for decades (USGS 2002). 


\section{Materials and Methods}

\subsection{Raw sewage- Source and analysis}

Raw sewage was collected from the sewage treatment plant (STP) in Anna University, CEG campus, Chennai. Samples were collected on weekly basis for ten weeks and subjected to physico-chemical and biological analysis. All the analysis were carried out according to the standard procedures (APHA 2017).

\subsection{Plants chosen for the study}

Based on the literature study, the sedge Cyperus alternifolius was chosen for the study with the idea of converting the harvested biomass into some useful product. Cyperus alternifolius commonly known as umbrella sedge belongs to the family Cyperaceae. It is a perennial plant capable of growing to a height of 4- 6 feet with higher percentage of fine fibrous root biomass. Healthy plantlets were purchased from Sri Venkateshwara farm, Injambakkam, Chennai. The culms can be used in making mats, hats and thatching. The species is perennial and locally available.

\subsection{Experimental setup for vertical flow constructed wetland system}

The site for the experimental set up was chosen near the sample source, explicitly in the sewage treatment plant, Anna University, CEG campus, Chennai. The constructed wetland was built with $5 \mathrm{~mm}$ acrylic sheets with the dimension of $1.2 \times 0.6 \times 0.7 \mathrm{~m}$ provided with a slope of 0.5 and an outlet for effluent collection.

The reed bed consisted of three layers: pebbles $(10 \mathrm{~cm})$, blue metal chips $(5 \mathrm{~cm})$, coarse sand $(15 \mathrm{~cm})$ and fine sand $(30 \mathrm{~cm})$ from bottom to top. Blue metal chips was sandwiched between the sand and pebbles to avoid the percolation of sand into the gaps created in the pebble layer. The porosity of the wetland was calculated from the formulae

$$
\text { Porosity } \%=\frac{\text { Void volume }}{\text { Total volume }} \times 100 \quad \text { (Cresswell and Hamilton 2002) }
$$

The wetland tank was covered with black cloth to prevent growth and interference of algae in the efficiency of the system. The experimental set up is shown in Figure 2.1.

Twelve plantlets were planted in the reed bed of each unit at equal intervals and saturated with diluted sewage for a period of 4 weeks for acclimatization and establishment of roots. The saturation aids in establishment of compact bed and association of microbial growth in reed bed and rhizome (Sehar et al. 2013). 


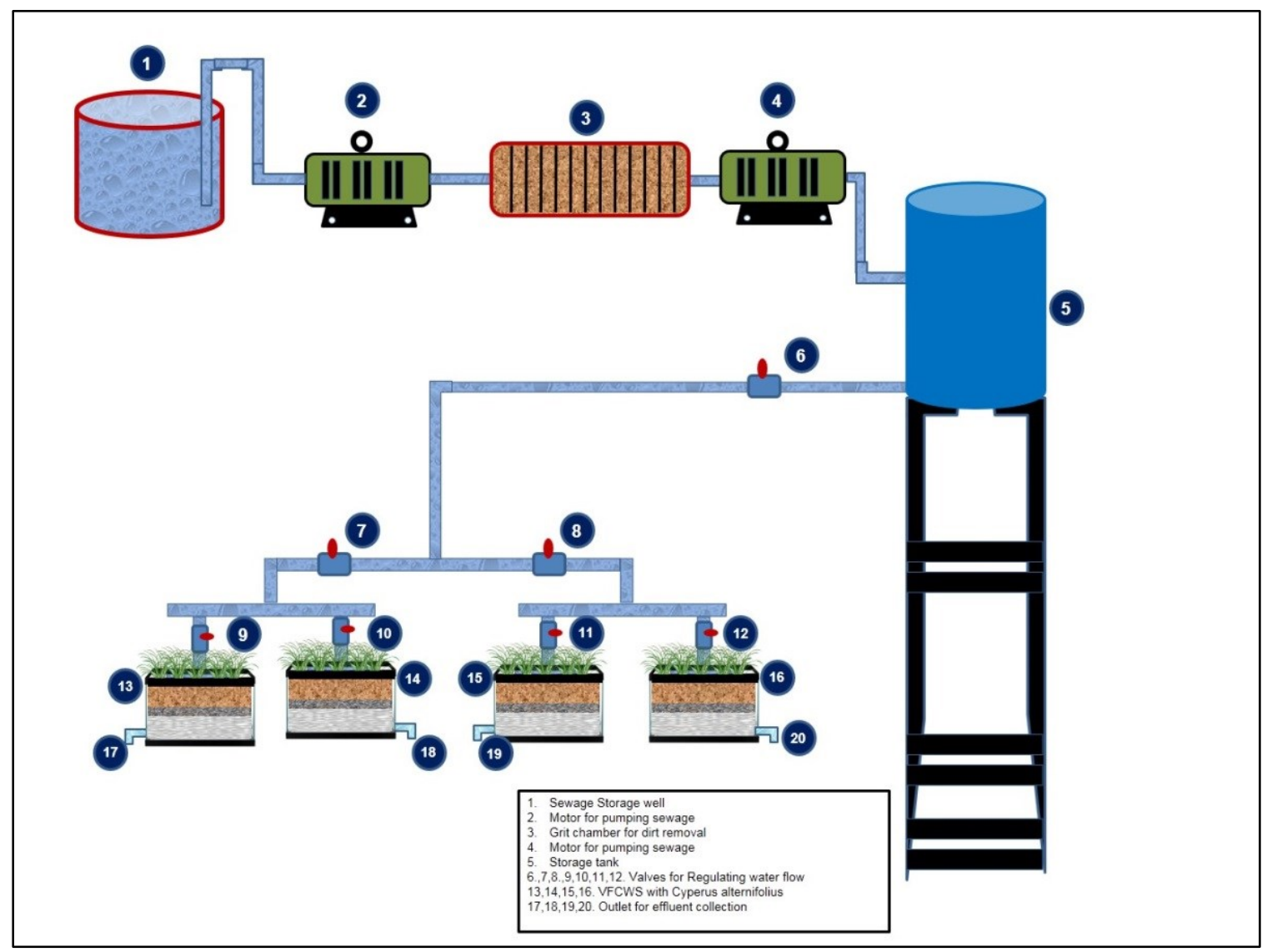

Figure 2.1 Experimental set up

Sewage was passed through grit chambers to segregate the debris and pumped into storage tank with a capacity of 210 liters. From the storage tank the wastewater was supplied into constructed wetland units. The influent was distributed evenly at the top through perforated pipe lines. Valves were set in the PVC pipes for regulation of water flow. Preliminary studies were conducted to monitor the plant growth of both species and compared with respective control.

\section{$2.4 \quad$ Optimisation of HLR}

The effect of HLR on removal efficiency was examined over a period of 16 weeks at four different hydraulic loading rates: $28 \mathrm{~mm} / \mathrm{d}(20 \mathrm{~L} / \mathrm{d}), 56 \mathrm{~mm} / \mathrm{d}(40 \mathrm{~L} / \mathrm{d}), 84 \mathrm{~mm} / \mathrm{d}(60 \mathrm{~L} / \mathrm{d})$ and 112 $\mathrm{mm} / \mathrm{d}(80 \mathrm{~L} / \mathrm{d})$. Hydraulic retention time $(\mathrm{HRT})$ of respective HLR was calculated theoretically from the formulae (Lee et al 2015).

$$
\mathrm{HRT}=\frac{\text { Volume of wetland } \mathrm{x} \text { porosity }}{\text { Flow rate }}
$$

Influent and effluent were collected at sampling interval of 7 days. All samples were analysed for BOD, COD, TKN, TSS, TDS, phosphate, and heavy metals. However, microbiological analysis for total coliforms, faecal coliforms and E. coli were performed on fortnight basis for the same period of study. All the analysis were carried out in triplicates and averaged. The optimal performance of the wetland was evaluated based on mass removal rate, removal efficiency of the pollutants, areal removal rate constant and volumetric removal rate constant. 


\subsubsection{Calculations}

The formulas used for the calculation are presented (Lee et al 2015).

$$
\text { Removal efficiency } \%=\frac{\mathrm{C}(\text { influent })-\mathrm{C}(\text { effluent })}{\mathrm{C}(\text { influent })} \times 100
$$

Where $\mathrm{C}$ represents concentration in $\mathrm{mg} / \mathrm{L}$.

Mass removal rate was calculated using the formula

$\mathrm{r}=\mathrm{q}(\mathrm{C}$ (influent) $-\mathrm{C}$ (effluent))

Where $\mathrm{q}$ is the hydraulic loading rate in $\mathrm{m} \mathrm{d}^{-1}$. Mass removal rate is expressed in $\mathrm{g} \mathrm{m}^{-2} \mathrm{~d}^{-1} \cdot \mathrm{q}=\mathrm{Q} / \mathrm{A}$. where $\mathrm{Q}$ is the flow rate through the wetland and $\mathrm{A}$ is the area of the wetland. The geo coordinate of sample collection was Latitude: 13.0127 Longitude: 80.2364.

\subsection{2 $\quad$ First order kinetics}

First order degradation approach was used to predict the removal efficiency of the system. Areal removal rate constant and volumetric removal rate constant were calculated for the pollutants BOD, COD, TSS, TKN and TP. Kadlec \& Wallace (2009) proposed the following equation for areal removal rate constant and the same equation was applied.

$$
\ln [(\mathrm{C} \text { (effluent) / C (influent) })]=-\mathrm{K}_{\mathrm{A}} / \mathrm{q} \text {. }
$$

Where $\mathrm{K}_{\mathrm{A}}$ is the areal removal rate constant in $\mathrm{m} \mathrm{d}^{-1}$ and $\mathrm{q}$ is the hydraulic loading rate in $\mathrm{m} \mathrm{d}^{-1}$.

The following equation for volumetric removal rate constant proposed by Reed et al. (1995) was applied.

$$
\ln [(\mathrm{C} \text { (effluent) / C (influent) })]=-\mathrm{K}_{\mathrm{v}} \mathrm{t} .
$$

Where $\mathrm{K}_{\mathrm{v}}$ is the volumetric removal rate constant in $\mathrm{d}^{-1}$ and $\mathrm{t}$ is the hydraulic retention time in the wetland.

\section{Result and Discussion}

\subsection{Characteristics of sewage}

The results of characterisation of the sewage with an average and standard deviation of sample size 10 are provided in Table 3.1. The $\mathrm{pH}$ range of domestic sewage from various cities of India ranges from 7 to 7.5 (CPCB 2005). The range of $\mathrm{pH}$ for domestic wastewater is 5.5 - 8 (Metcalf $\&$ Eddy 2003). But present study reveals that sewage is slightly alkaline in nature. Similar alkaline $\mathrm{pH}$ range is reported by Sonune et al. (2015). Fresh sewage is alkaline in nature. However, near neutral $\mathrm{pH}$ were also reported. If biological treatment is preferred the $\mathrm{pH}$ should be in the range of 68 for efficient action of microbes.

Electrical conductivity (EC) is a measure of the suitability of water for irrigation. Higher EC values indicates salinity. Irrigation with sewage contaminated water increases the electrical conductivity of the soil (Shresta et al 2017). The range of electrical conductivity in the present study revealed sewage as medium strength. 
Table 3.1 Characteristics of sewage

\begin{tabular}{|l|c|}
\hline \multicolumn{1}{|c|}{ Parameters } & Mean \pm S.D \\
\hline Ph & $7.8 \pm 0.5$ \\
\hline Electrical conductivity $\left(\mu \mathrm{scm}^{-1}\right)$ & $550 \pm 100$ \\
\hline BOD $(\mathrm{mg} / \mathrm{L})$ & $250 \pm 22$ \\
\hline COD $(\mathrm{mg} / \mathrm{L})$ & $360 \pm 25$ \\
\hline TKN $(\mathrm{mg} / \mathrm{L})$ & $24 \pm 5$ \\
\hline Nitrate nitrogen $(\mathrm{mg} / \mathrm{L})$ & $1.5 \pm 0.5$ \\
\hline Ammoniacal nitrogen $(\mathrm{mg} / \mathrm{L})$ & $14 \pm 2$ \\
\hline Total phosphate $(\mathrm{mg} / \mathrm{L})$ & $4.3 \pm 0.9$ \\
\hline Sulphate $(\mathrm{mg} / \mathrm{L})$ & $48 \pm 8$ \\
\hline Chlorides $(\mathrm{mg} / \mathrm{L})$ & $56 \pm 5$ \\
\hline TSS $(\mathrm{mg} / \mathrm{L})$ & $312 \pm 30$ \\
\hline TDS $(\mathrm{mg} / \mathrm{L})$ & $425 \pm 35$ \\
\hline Cadmium $(\mathrm{mg} / \mathrm{L})$ & $\mathrm{BDL}$ \\
\hline Chromium $(\mathrm{mg} / \mathrm{L})$ & $0.23 \pm 0.02$ \\
\hline Copper $(\mathrm{mg} / \mathrm{L})$ & $0.58 \pm 0.03$ \\
\hline Zinc $(\mathrm{mg} / \mathrm{L})$ & $2.6 \pm 0.23$ \\
\hline Aluminium $(\mathrm{mg} / \mathrm{L})$ & $2.3 \pm 0.21$ \\
\hline Nickel $(\mathrm{mg} / \mathrm{L})$ & $0.12 \pm 0.02$ \\
\hline Iron $(\mathrm{mg} / \mathrm{L})$ & $5.2 \pm 0.5$ \\
\hline Lead $(\mathrm{mg} / \mathrm{L})$ & $0.22 \pm 0.02$ \\
\hline Total coliform $(\mathrm{MPN} / 100 \mathrm{~mL})$ & $3.2 \times 10^{6}$ to $1.2 \times 10^{8}$ \\
\hline Fecal coliform $(\mathrm{MPN} / 100 \mathrm{~mL})$ & $68.4 \times 10^{5}$ to $32 \times 10^{7}$ \\
\hline E. coli $(\mathrm{MPN} / 100 \mathrm{~mL})$ & $12.3 \times 10^{4}$ to $3.3 \times 10^{6}$ \\
\hline Detectable $\mathrm{Limit}(0.01 \mathrm{ppm})$ & \\
\hline & \\
\hline
\end{tabular}

BDL $^{*}$ - Below Detectable Limit (0.01 ppm)

Increase in soil salinity is attributed by usage of sewage in irrigation or leakage of sewers. The value of BOD for raw sewage is generally in the range of $100-400 \mathrm{mg} / \mathrm{L}$ in Indian cities. An average of 106 samples in Indian cities revealed a mean of $185.5 \mathrm{mg} / \mathrm{L}$ (CPCB 2005). An average BOD of 205 and $228.5 \mathrm{mg} / \mathrm{L}$ were reported in STPs located in Delhi and Madurai respectively. The typical range of BOD in domestic wastewater is 100-300 mg/L (Metcalf \& Eddy 2003). The COD value ranges between $200-700 \mathrm{mg} / \mathrm{L}$ in $83 \%$ of observed cities in India with an average of $481 \mathrm{mg} / \mathrm{L}$ (CPCB 2005).

Biodegradability is a good index for organic degradation and calculated from BOD/COD ratio. Generally it ranges from $0.4-0.8$ in raw sewage and differs for different types of wastewater. In our study, the BOD/COD ratio is 0.7 indicating that it can be best treated by biological means rather than chemical process.

The TKN (Total Kjeldahl Nitrogen) is the combination of ammoniacal nitrogen and organic nitrogen with a range of $20-85 \mathrm{mg} / \mathrm{L}$. In municipal wastewater, it ranges from 35 to $60 \mathrm{mg} / \mathrm{L}$. TP (Total Phosphate) in domestic wastewater ranges from 5 to $10 \mathrm{mg} / \mathrm{L}$. Sulphate concentration in sewage is $20-50 \mathrm{mg} / \mathrm{L}$. Typical untreated municipal wastewater had a TSS (Total Suspended Solids) of $100-360 \mathrm{mg} / \mathrm{L}$ (Metcalf \& Eddy 2003). Correlation between electrical conductivity and TDS was evaluated by Uwidia \& Ukulu (2013) and our results well agree with it. Prerequisite changes in characterisation of wastewater is likely to occur from one location to another. Even in specific location, the composition varies from time to time.

The allowable limits of heavy metals by CPCB, India are presented in Table 3.2. Results revealed that heavy metals iron and lead exceeded the permissible limit. Hence, these 2 heavy metals were taken into consideration for further studies and other heavy metals zinc, aluminium, copper, cadmium, chromium and nickel were neglected as they are well below the allowable limits. However, the metals $\mathrm{Cu}, \mathrm{Zn}, \mathrm{Ni}$ are considered as micronutrients required for plant growth. Soil irrigated with sewage is contaminated with various heavy metals and long term application of sewage in irrigation may lead to piling up of heavy metal concentration in cultivable land and pass on to the ecosystem via food, posing threat to all living beings (Usharani \& Vasudevan 2014). 
Table 3.2 Comparison of heavy metal concentration in sewage with permissible limit

\begin{tabular}{|l|c|c|}
\hline \multicolumn{1}{|c|}{ Heavy metal } & Concentration in sewage & Permissible limit \\
\hline Cadmium $(\mathrm{mg} / \mathrm{L})$ & BDL $^{*}$ & 2 \\
\hline Chromium $(\mathrm{mg} / \mathrm{L})$ & $0.23 \pm 0.02$ & 2 \\
\hline Copper $(\mathrm{mg} / \mathrm{L})$ & $0.58 \pm 0.03$ & 3 \\
\hline Zinc $(\mathrm{mg} / \mathrm{L})$ & $2.6 \pm 0.23$ & 5 \\
\hline Aluminium $(\mathrm{mg} / \mathrm{L})$ & $2.3 \pm 0.21$ & 5 \\
\hline Nickel $(\mathrm{mg} / \mathrm{L})$ & $0.12 \pm 0.01$ & 3 \\
\hline Iron $(\mathrm{mg} / \mathrm{L})$ & $5.2 \pm 0.5$ & 3 \\
\hline Lead $(\mathrm{mg} / \mathrm{L})$ & $0.22 \pm 0.02$ & 0.1 \\
\hline
\end{tabular}

BDL $^{*}$ - Below Detectable Limit (0.01 ppm)

\subsection{Optimisation of HLR - First order kinetics}

Published literature on optimisation studies revealed that application of first order kinetics fitted well for removal efficiency of BOD, COD, TSS, TKN and TP. The theoretical HRT for the respective HLR with flow rate is presented in Table 3.3.

Table 3.3 HRT of respective HLR

\begin{tabular}{|c|c|c|}
\hline Flow rate & HLR & HRT (days) \\
\hline $0.02 \mathrm{~m}^{3} / \mathrm{d}$ & $28 \mathrm{~mm} / \mathrm{d}$ & 12 \\
\hline $0.04 \mathrm{~m}^{3} / \mathrm{d}$ & $56 \mathrm{~mm} / \mathrm{d}$ & 6.8 \\
\hline $0.06 \mathrm{~m}^{3} / \mathrm{d}$ & $84 \mathrm{~mm} / \mathrm{d}$ & 4.32 \\
\hline $0.08 \mathrm{~m}^{3} / \mathrm{d}$ & $112 \mathrm{~mm} / \mathrm{d}$ & 3.24 \\
\hline
\end{tabular}

The mass removal rate, $\mathrm{k}$ values of areal removal rate constant and volumetric removal rate constant of the present study is presented in Table 3.4. In the present study, first order kinetics fitted well for removal of organics and nutrients till $84 \mathrm{~mm} / \mathrm{d}$. The removal efficiency at the highest HLR of $112 \mathrm{~mm} / \mathrm{d}$ is slightly less. It may be due to little over loading and spillage of influent. Similar condition was explained by Trang et al. (2010), at HLR $146 \mathrm{~mm} / \mathrm{d}$. In HFCWS, applying Kickuth equation of first order kinetics revealed that hydraulic and pollutant loading strongly influenced wetland performance in removal of organics. Monad model of first order kinetics predicted the removal of nitrogen in constructed wetland system (Gajewska \& Skrzypiec 2018). Trang et al. (2010), conducted experiments under tropical climatic conditions at 4 HLRs: $31 \mathrm{~mm} / \mathrm{d}, 62 \mathrm{~mm} / \mathrm{d}, 104 \mathrm{~mm}$ $/ \mathrm{d}$ and $146 \mathrm{~mm} / \mathrm{d}$ and concluded that applying first order kinetics fitted well for all parameters up to $104 \mathrm{~mm} / \mathrm{d}$. In the present study, $\mathrm{K}_{v}$ and $\mathrm{K}_{A}$ values were similar for BOD, COD, TKN and TSS while, the values of TP was little lesser confirming the significant removal range of the pollutants.

Higher values were obtained at HLR $84 \mathrm{~mm} / \mathrm{d}$ for organics (BOD and COD) and nutrients (TKN and TP) removal confirming the optimal load of existing system. The quality of influent corresponds to typical municipal wastewater and the quality of effluent remained consistent after a period of 9 weeks at all hydraulic loading rate. Stabilization of the system was attained after maximal growth of plants to a height of 5-6 feet in 9 weeks. The removal efficiency remains constant in a fully matured VFCWS (Stefanakis \& Tsihrintzis 2012). 
Table 3.4 Rate constant values and mass removal rate at different HLRs

\begin{tabular}{|c|c|c|c|c|}
\hline Parameters & $\begin{array}{l}\text { HLR } \\
\mathrm{mm} / \mathrm{d}\end{array}$ & $\begin{array}{l}\text { Mass removal } \\
\text { rate }\left(\mathrm{g} \mathrm{m}^{-2} \mathrm{~d}^{-1}\right)\end{array}$ & $\begin{array}{c}\text { Areal removal rate } \\
\text { constant } \\
K_{A}\left(\mathrm{~m} \mathrm{~d}^{-1}\right) \\
\end{array}$ & $\begin{array}{c}\text { Volumetric removal rate } \\
\text { constant } \\
K_{V}\left(\mathrm{~d}^{-1}\right) \\
\end{array}$ \\
\hline \multirow{4}{*}{ BOD } & 28 & 4.06 & 0.02 & 0.07 \\
\hline & 56 & 9.07 & 0.06 & 0.17 \\
\hline & 84 & 18.06 & 0.18 & 0.52 \\
\hline & 112 & 20.38 & 0.15 & 0.43 \\
\hline \multirow{4}{*}{ COD } & 28 & 6.16 & 0.02 & 0.08 \\
\hline & 56 & 13.16 & 0.06 & 0.17 \\
\hline & 84 & 26.04 & 0.18 & 0.5 \\
\hline & 112 & 28.56 & 0.14 & 0.40 \\
\hline \multirow{4}{*}{ TSS } & 28 & 6.9 & 0.04 & 0.12 \\
\hline & 56 & 14.4 & 0.09 & 0.25 \\
\hline & 84 & 23.9 & 0.18 & 0.51 \\
\hline & 112 & 28.5 & 0.17 & 0.49 \\
\hline \multirow{4}{*}{ TKN } & 28 & 0.57 & 0.04 & 0.12 \\
\hline & 56 & 1.21 & 0.10 & 0.27 \\
\hline & 84 & 1.97 & 0.19 & 0.54 \\
\hline & 112 & 2.35 & 0.18 & 0.50 \\
\hline \multirow{4}{*}{$\mathrm{TP}$} & 28 & 0.07 & 0.02 & 0.08 \\
\hline & 56 & 0.18 & 0.07 & 0.20 \\
\hline & 84 & 0.30 & 0.13 & 0.37 \\
\hline & 112 & 0.33 & 0.12 & 0.33 \\
\hline
\end{tabular}

\subsubsection{Removal of organics in VFCWS}

The concentration of BOD in the influent ranged from 216-252 $\mathrm{mg} / \mathrm{L}$. As the HLR increases, the removal rate of organics increased till $84 \mathrm{~mm} / \mathrm{d}$ with HRT of 4.32 days. Maximum removal efficiency of organics was achieved at $84 \mathrm{~mm} / \mathrm{d}$. The BOD concentration in the influent and effluent with removal efficiency of VFCWS is depicted in Figure 3.1. In the present study, a maximum of $80-88 \%$ removal of BOD was achieved at $84 \mathrm{~mm} / \mathrm{d}$. BOD removal of $50-56 \%$, 54$63 \%$ and $64-73 \%$ was achieved for $28 \mathrm{~mm} / \mathrm{d}, 56 \mathrm{~mm} / \mathrm{d}$ and $112 \mathrm{~mm} / \mathrm{d}$ respectively. The respective concentration of BOD in the effluent at maximal removal \% was 95, 78, 25 and $58 \mathrm{mg} / \mathrm{L}$ for $28 \mathrm{~mm} / \mathrm{d}$, $56 \mathrm{~mm} / \mathrm{d}, 84 \mathrm{~mm} / \mathrm{d}$ and $112 \mathrm{~mm} / \mathrm{d}$ respectively. The removal of BOD increased steadily till 9 weeks. However, the removal \% tends to remain stable and constant after 9 weeks. The reason might be due to time period to attain the stabilisation of the system. Moreover, the plants reached a maximum height of 5 feet within that time duration indicating a fully matured VFCWS. In a fully matured VFCWS as the HLR increases, the rate of organic removal increases (Stefanakis \& Tsihrintzis 2012).

According to Klomjek (2016) when HLR was increased from $2 \mathrm{~cm} / \mathrm{d}$ to $5 \mathrm{~cm} / \mathrm{d}$ the removal efficiency of BOD increased from $86 \pm 4 \%$ to $94 \pm 1 \%$ in CWS planted with giant Napier grass. Transformation of pollutants vary with depth and is a crucial factor in determining contaminant removal by affecting the redox status and dissolved oxygen level in CWS. The microbial community is highly active near the root zone favouring organic removal (Prajapati et al. 2017).

Yang et al. (2017) reported that as the OLR increases, the removal rate of BOD and COD in aerobic bio filters increased. The efficiency of wetland in organic removal is higher in summer than other seasons (Ramakrishna Rao et al. 2013). The removal efficiency of VFCWS for organic removal is reported to be above $90 \%$ in several studies (Luederitz et al. 2001). Removal of 95.3-99\% of BOD was achieved in hybrid CWS (Lee et al. 2015). 


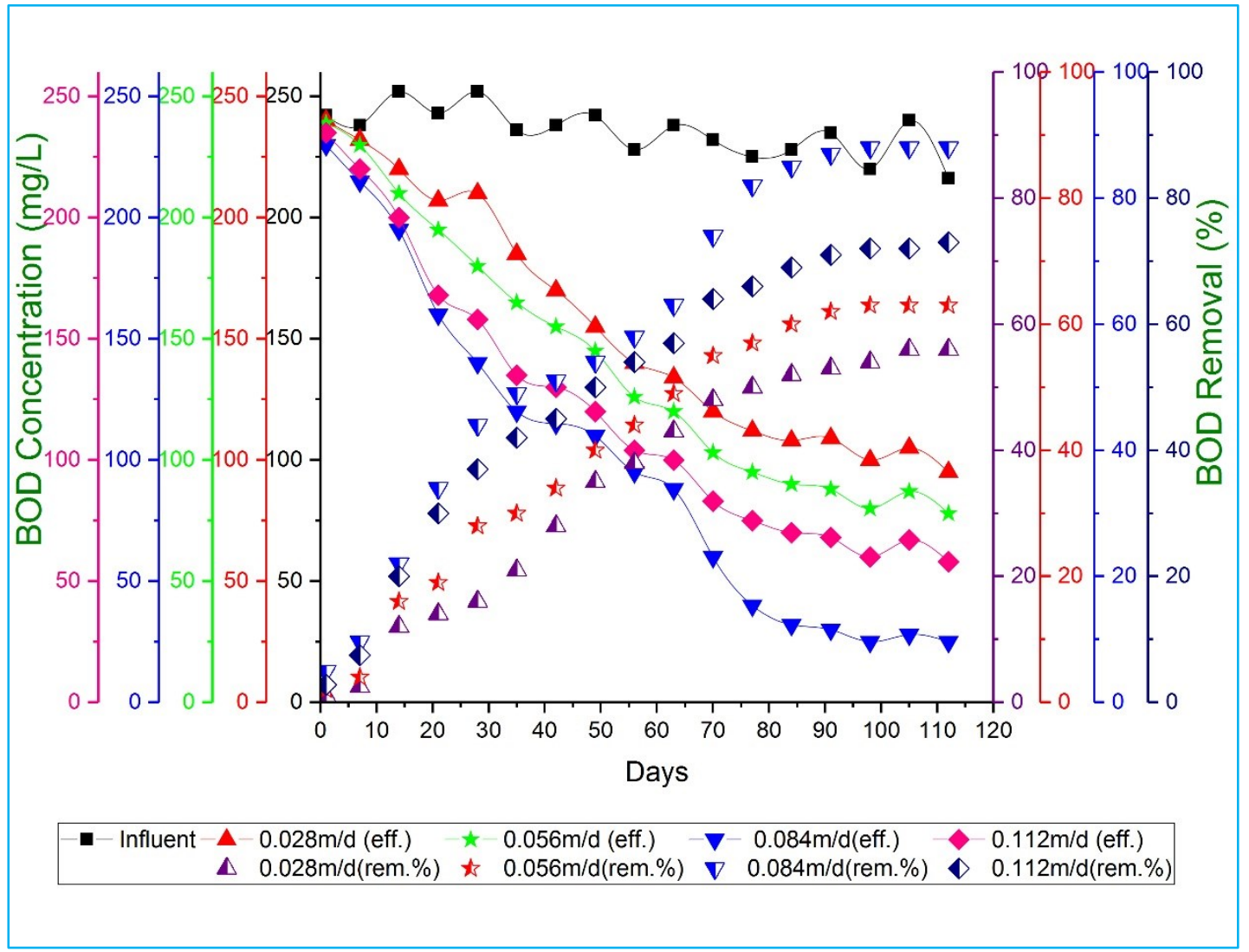

Figure 3.1 BOD removal in VFCWS

The concentration of COD in the influent ranged from 320-360 mg/L. The COD concentration and removal efficiency of VFCWS is shown in Figure 3.2. Maximum of 78-88\% removal of COD was attained at $84 \mathrm{~mm} / \mathrm{d}$ while, removal of $52-60 \%, 59-66 \%$ and $66-72 \%$ was achieved for 28,56 and $112 \mathrm{~mm} / \mathrm{d}$ respectively. The respective concentration of COD in the effluent at maximal removal \% was 135, 115, 40 and $95 \mathrm{mg} / \mathrm{L}$ for $28 \mathrm{~mm} / \mathrm{d}, 56 \mathrm{~mm} / \mathrm{d}, 84 \mathrm{~mm} / \mathrm{d}$ and 112 $\mathrm{mm} / \mathrm{d}$ respectively. As in the case of BOD, a steady increase in the removal of COD was observed till a period of 9 weeks and stabilization of the system was achieved after 9 weeks. Most of the studies in CWS reveal 76-99\% and 78.80-98.46\% removal of BOD and COD respectively (Qomariyah et al. 2017). Our results correlate with the findings of Ebrahimi et al. (2013) where, an average of $83 \%$ of COD removal from municipal wastewater was attained by Cyperus alternifolius. Studies conducted by Shahi et al. (2013) revealed that Cyperus alternifolius was a better candidate than Phragmites australis for removal of organics, nutrients and heavy metals from the system except microbiological parameter. Comparative results of removal efficacy of two different species revealed that Phragmites australis was effective in removal of organics than Typha latifolia (Andreo- Martinez et al. 2016) with a removal efficiency of $96.4 \%$ BOD and $84.6 \%$ COD. 


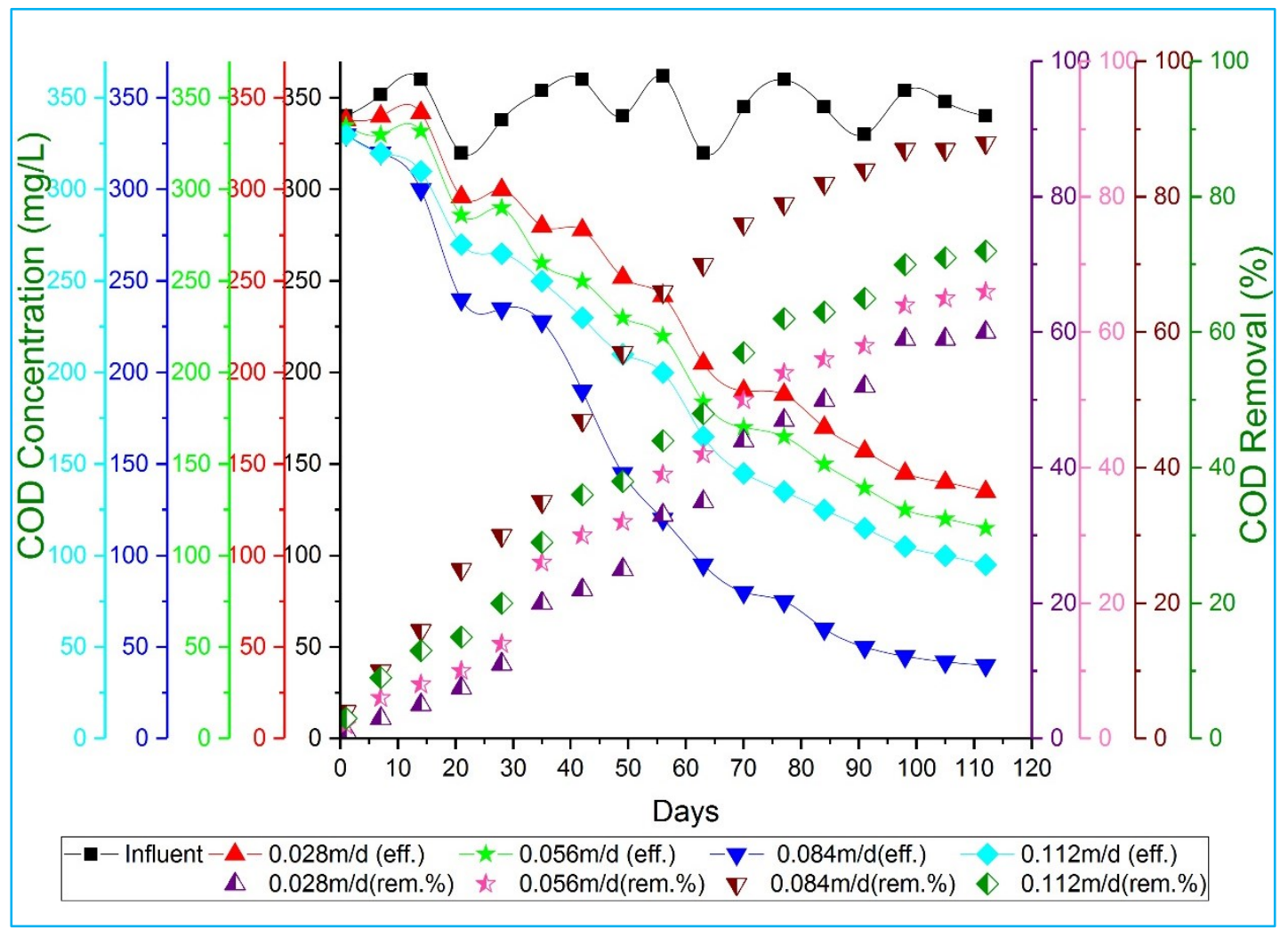

Figure 3.2 COD removal in VFCWS

Generally, CWS achieves an outlet of less than $25 \mathrm{mg} / \mathrm{L}$ of BOD in summer with maximum removal of $94.9 \%$ BOD and $96.7 \%$ COD (Tole et al. 2014). Above $15^{\circ} \mathrm{C}, 90.5 \%$ of BOD and $90.8 \%$ COD removal was achieved and lesser removal efficiency is reported at temperature lesser than $15^{\circ} \mathrm{C}$ (Akratos \& Tsihrintzis 2007). India being a country tropical climate, maximal removal of organics can be well accomplished.

CWS planted with Typha angustifolia and Phragmites australis had $>75 \%$ BOD removal in domestic wastewater (Karathanasis et al. 2003). About 96.1\% BOD and 94.5\% COD was attained in CWS planted with Typha latifolia, Cyperus papyrus and Phragmites australis (Nzengya \& Wishitemi 2001). CWS treating sewage planted with Eichornia crassipes is capable of removing 95.89\% and 97\% of BOD and COD (Yadav et al. 2011).

In VFCWS, BOD and COD removal efficiency of CWS planted with Phragmites australis were $92.3 \%$ and $91.7 \%$ (Gikas et al. 2007), 77.99\% BOD removal and 76.16\% COD removal (Sudarsan et al. 2015), 84\% and 75\% of BOD and COD removal (Abdelhakeem et al. 2016). From this it can be inferred that even for the same species the removal rate differs depending upon diverse factors: geographical condition, design of the wetland, substrate used and the quality of the influent. The removal of organics is much higher in vertical flow than horizontal flow constructed wetlands (Lee et al. 2015). Cyperus papyrus and Phragmites mauritianus efficiently removed $81.22 \%$ COD and $78.37 \%$ BOD while, Cyperus alone contributed to $73.76 \%$ COD and $75.78 \%$ BOD removal (Nzabuheraheza et al. 2012). CWS treating domestic wastewater with integrated plantation of Typha and Phragmites showed a removal efficiency of 92\% BOD and 86\% COD (Mirunalini et al. 2014). In hybrid CWS, treating domestic wastewater planted with Paspalidium flavidum $97.55 \%$ of COD and $97.5 \%$ of BOD removal was achieved (Sehar et al. 2013).

\subsubsection{Removal of nutrients in VFCWS}

The concentration of TKN in the influent ranged from 24-30 mg/L. As the HLR increases, the removal of nutrients increased till $84 \mathrm{~mm} / \mathrm{d}$ with HRT of 4.32 days. The influent and effluent concentration and TKN removal efficiency of VFCWS is shown in Figure 3.3. From the results it can be inferred that maximum removal of $82-84 \%$ of TKN was accomplished at $84 \mathrm{~mm} / \mathrm{d}$ and removal efficiency of $63-70 \%, 60-76 \%$ and $65-72 \%$ was attained for $28 \mathrm{~mm} / \mathrm{d}, 56 \mathrm{~mm} / \mathrm{d}$ and $112 \mathrm{~mm} / \mathrm{d}$ 
respectively. The respective concentration of TKN in the effluent at maximal removal $\%$ was $7.5,6$, 4 and $7.2 \mathrm{mg} / \mathrm{L}$ for $28 \mathrm{~mm} / \mathrm{d}, 56 \mathrm{~mm} / \mathrm{d}, 84 \mathrm{~mm} / \mathrm{d}$ and $112 \mathrm{~mm} / \mathrm{d}$ respectively. At the maximum HLR $112 \mathrm{~mm} / \mathrm{d}$, a slight decrease in removal efficiency might be due to over loading. The stability of the system in nutrient removal is attributed by an increase in the number of lateral roots. Accomplishment of lateral root production might be achieved when the plant attains maximal growth.

Nitrogen is up taken by plants, stored in sediments and apart from that microbial nitrification and denitrification process takes place. Biological process of nitrification involves 2 steps: The conversion of ammonia into nitrite and conversion of nitrite into nitrate. E. coli is reported to reduce nitrate to ammonia (Gonzalez et al. 2006). Denitrification was retarded at higher salinity of $15 \mathrm{ppm}(\mathrm{Wu}$ et al. 2008). The wastewater characteristics of the present study confine salinity of medium strength which does not have much interference with denitrification process.

In a fully matured VFCWS as the HLR increases, the rate of nitrogen removal increases (Stefanakis \& Tsihrintzis 2012). Lower HRT in CWS is associated with incomplete denitrification of wastewater because $\mathrm{N}$ removal requires longer HRT than organic removal (Lee et al. 2015). As OLR increases, the removal rate of ammoniacal nitrogen in aerobic biofilters increased (Yang et al. 2017). Nitrogen removal is higher in vertical flow because it provides the suitable conditions for nitrification process and removal of $19-53.3 \%$ of TKN was achieved in hybrid constructed wetland system (Lee et al. 2015).

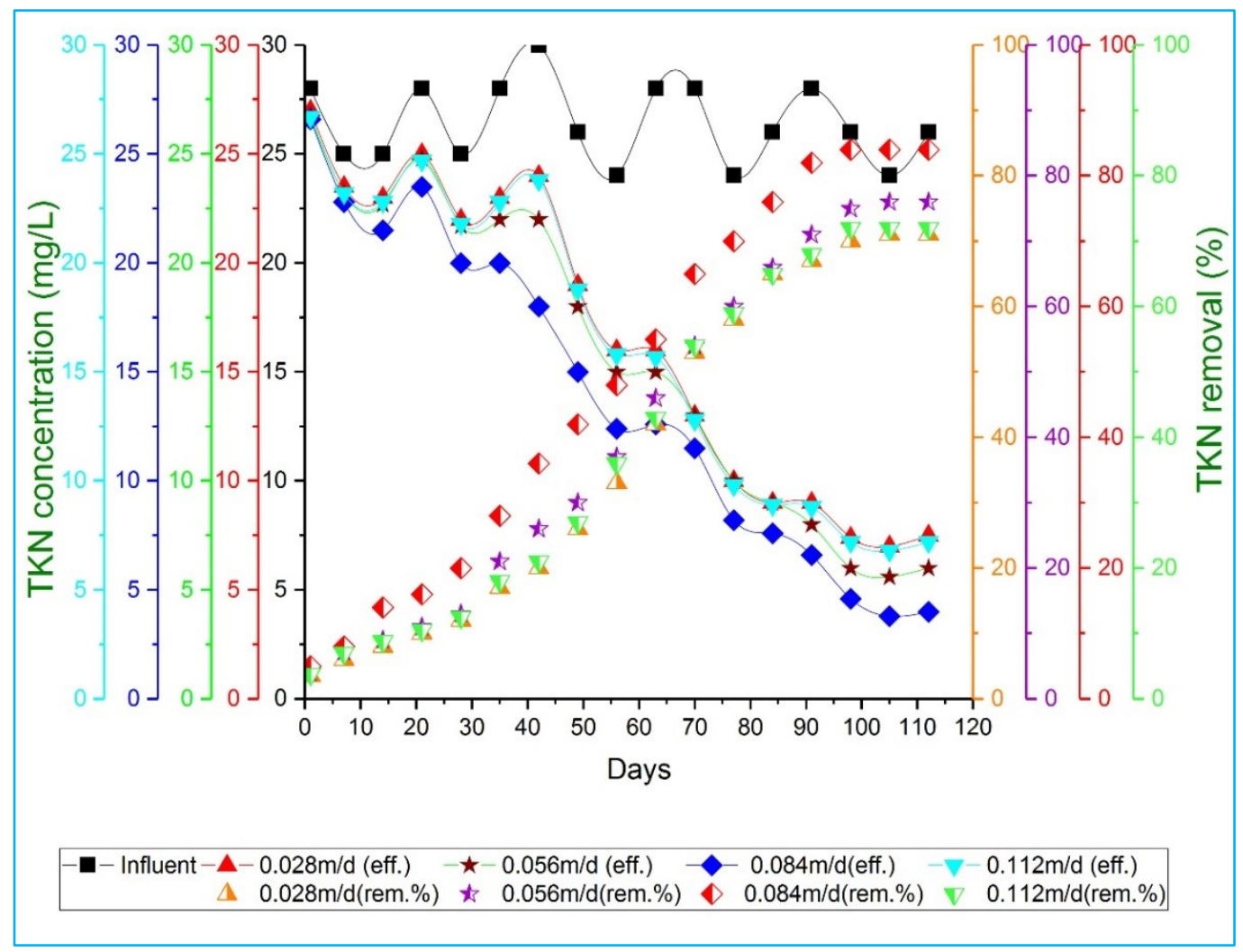

Figure 3.3 TKN removal in VFCWS

The concentration of phosphate in the influent ranged from 4.2-5.2 $\mathrm{mg} / \mathrm{L}$. The influent and effluent concentration and TP removal efficiency of VFCWS is shown in Figure 3.4. Results reveal maximum removal of $66-68 \%$ of TP at $84 \mathrm{~mm} / \mathrm{d}$ and removal efficiency of $30-36 \%, 52-56 \%$ and $54-60 \%$ for $28 \mathrm{~mm} / \mathrm{d}, 56 \mathrm{~mm} / \mathrm{d}$ and $112 \mathrm{~mm} / \mathrm{d}$ respectively. The respective concentration of TP in the effluent at maximal removal \% was 4.6, 2.9, 2 and $1.4 \mathrm{mg} / \mathrm{L}$ for $28 \mathrm{~mm} / \mathrm{d}, 56 \mathrm{~mm} / \mathrm{d}, 84 \mathrm{~mm} / \mathrm{d}$ and $112 \mathrm{~mm} / \mathrm{d}$ respectively. Phosphate removal in CWS is majorly accomplished by adsorption and precipitation in sand. In our study about three fourth of the media is constituted by sand that might have played a major role. River sand has excellent phosphate removal property (Trang et al. 2010). The mechanism for phosphate removal might be due to adsorption and/or precipitation in sand filter, plant uptake and microbial action. 


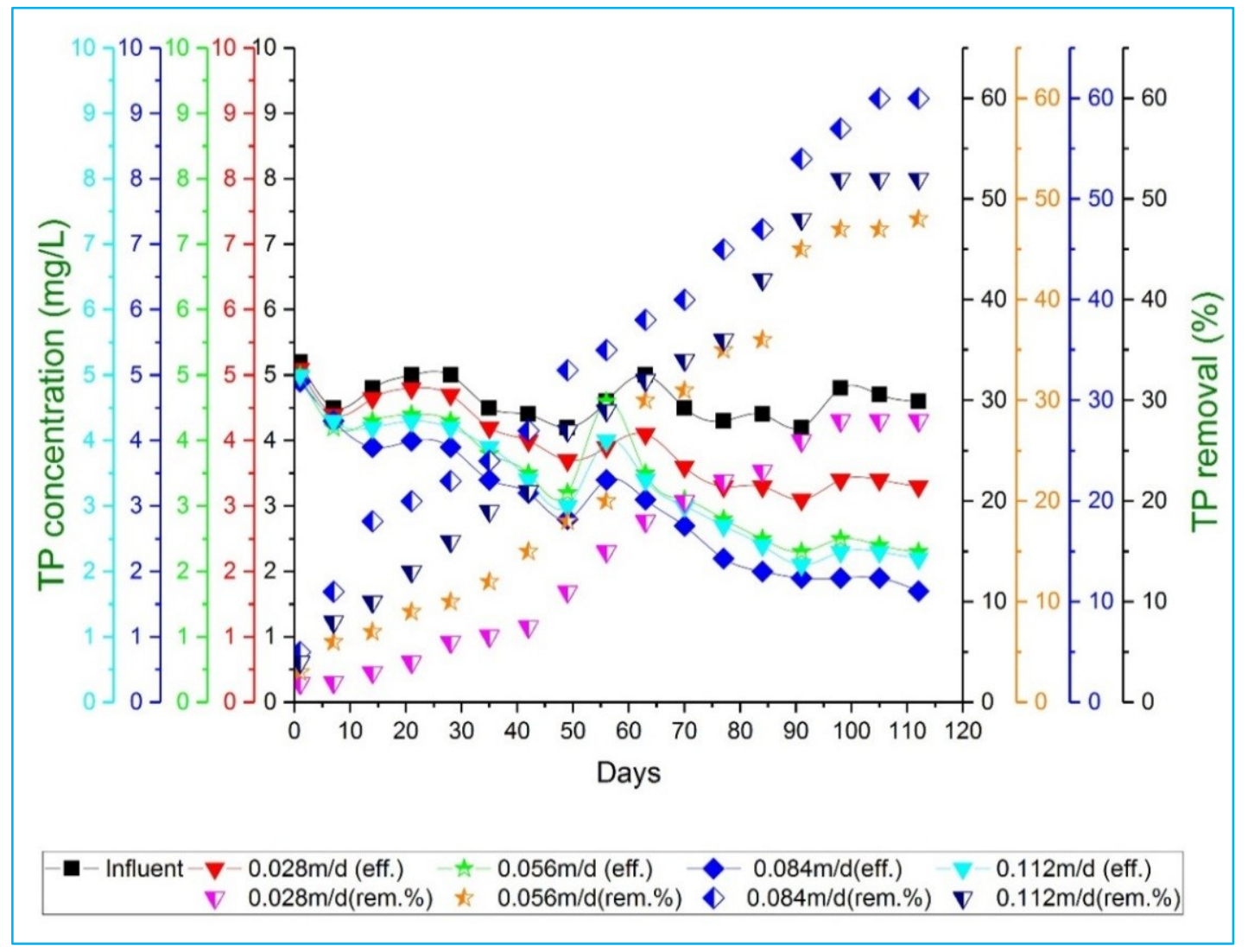

Figure 3.4 TP removal in VFCWS

Emblematic removal of phosphorus in the wetlands ranges from $40-60 \%$. However, Cyperus species is capable of up taking phosphate equivalent to Phragmites and our results correlate with Gikas et al. (2007). Latrach et al. (2015) reported a removal of 82 and 80\% of TKN and TP from domestic wastewater when multi layered substrate was used. Gikas et al. (2007) reported removal of 80.3\% TKN and 67.3\% TP in wetlands planted with Phragmites australis. Above $90 \%$ of nutrient removal can be achieved in wetlands depending on the performance of species and system as a whole (Luederitz et al. 2001).

In the previous studies a removal of $58.03 \%$ and $27.5 \%$ of TP was achieved by Phragmites australis in VFCWS and HFCWS respectively indicating that vertical flow achieves higher removal $\%$ than horizontal for the same species (Sudarsan et al. 2015, Mesquita et al. 2017). Maximum of $63.2 \%$ of TP was reported in hybrid constructed wetland (Lee et al. 2015). The microbial enzyme phosphatase is responsible for phosphate removal in CWS. The microbes in wastewater and soil contributes to $7 \%$ and $6 \%$ and adsorption in soil contributes to $71 \%$. According to Kumar et al. (2011) a maximum of $64-75 \%$ of TP is removed by adsorption process in the system, $9-19 \%$ by plant uptake and $7-12 \%$ by microbial metabolism. Cyperus papyrus has the ability to uptake $28.5 \%$ of nitrogen and $11.2 \%$ of phosphate from the system (Kyambadde et al. 2005).

The efficiency of wetland in nutrient removal is higher in summer than other seasons (Ramakrishna Rao et al. 2013, Mesquita et al. 2017). CWS with Eichornia crassipes treating sewage revealed removal of $43.07 \%$ and $49.03 \%$ for nitrogen and TP (Yadav et al. 2011). Temperature majorly influences the removal of ammoniacal nitrogen, total nitrogen and total phosphate (Akratos \& Tsihrintzis 2007). In HFCWS, Phragmites is efficient in removing $79.5 \%$ of $\mathrm{N}$ and $83.7 \%$ of TP (Andreo- Martinez et al. 2016). CWS with integrated plantation of Typha and Phragmites could achieve $84 \%$ of TN and $75 \%$ of TP removal (Mirunalini et al. 2014). In hybrid CWS, planted with Paspalidium flavidum $89.35 \%$ of TP was removed from domestic wastewater influent (Sehar et al. 2013). 


\subsubsection{Removal of coliform in VFCWS}

The pathogen removal in CWS of the present study reveals $99.99 \%$ removal of total coliforms (TC), fecal coliforms (FC) and E.coli corresponding to 2-3 log removal. The range of TC in the inlet ranges from $4.3 \times 10^{6}-37.8 \times 10^{7} \mathrm{MPN} / 100 \mathrm{~mL}$ respectively. Consistent removal of TC, FC and E.coli was attained after 8 weeks period of time. Log removal of TC increased from 0.93-2.3, 0.8-1.7, 0.6-1.6 and 0.14-0.5 for $28 \mathrm{~mm} / \mathrm{d}, 56 \mathrm{~mm} / \mathrm{d}, 84 \mathrm{~mm} / \mathrm{d}$ and $112 \mathrm{~mm} / \mathrm{d}$ respectively during the first seven weeks.

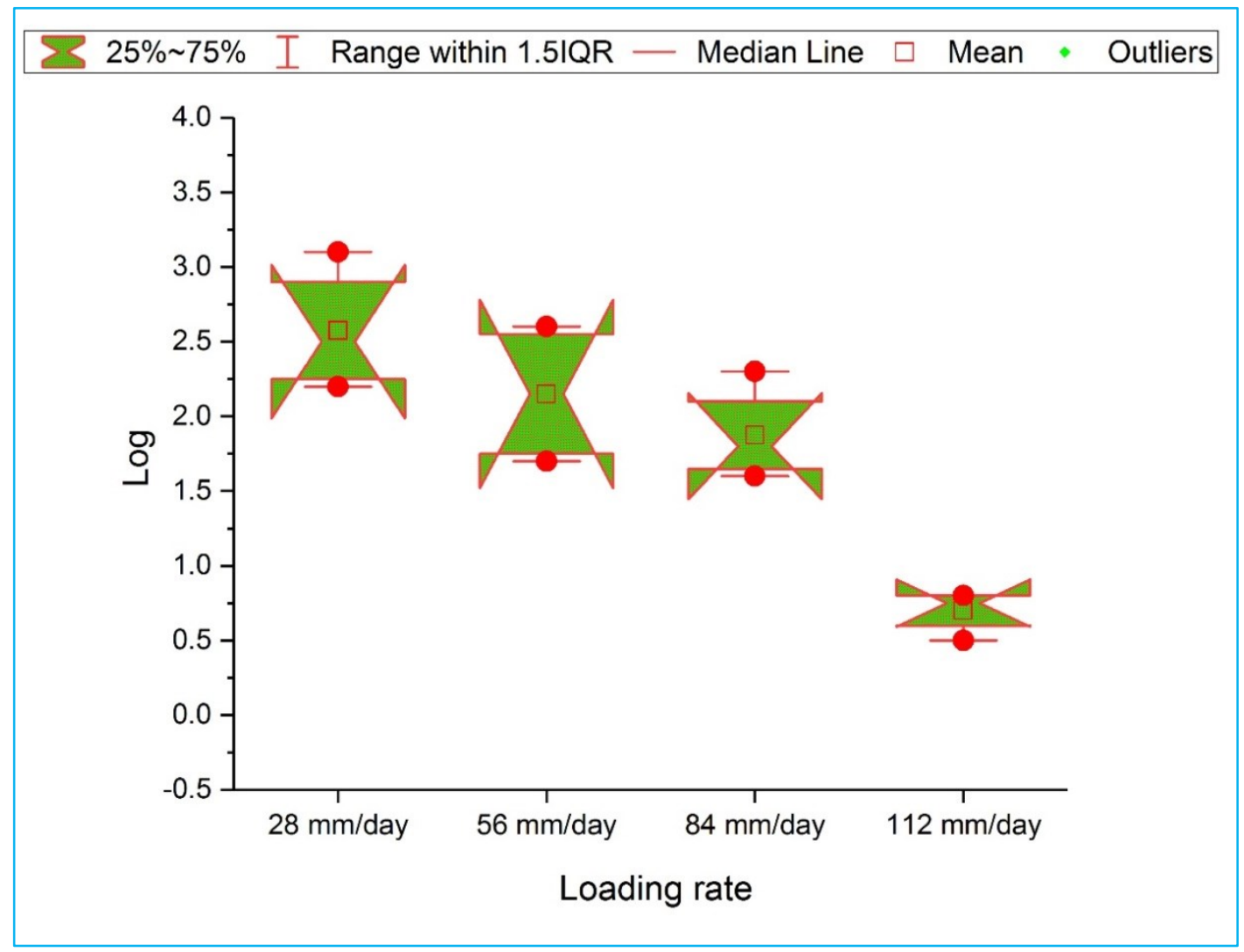

Figure 3.5 Reduction of TC at different HLRs

After $8^{\text {th }}$ week, a maximum of $3.1 \mathrm{log}$ reduction was achieved at $28 \mathrm{~mm} / \mathrm{d}$ whereas, 2.6 $\log$ removal, $2.3 \log$ removal and $0.9 \log$ removal was achieved for $56 \mathrm{~mm} / \mathrm{d}, 84 \mathrm{~mm} / \mathrm{d}$ and $112 \mathrm{~mm}$ /d respectively. The log reduction of total coliforms in CWS at different HLR is presented in Figure 3.5. The lowest HLR had the retention time of 12 days. Increased retention time might have favoured maximum removal. About $99.99 \%$ of pathogen reduction is reported by several authors in different constructed wetlands with different species equivalent to 3-4 log reduction (Tole et al. 2014).

The concentration of FC in the inlet ranged from $4.9 \times 10^{5}$ to $11.5 \times 10^{6} \mathrm{MPN} / 100 \mathrm{~mL}$. The $\log$ reduction of fecal coliforms in CWS at different HLR is presented in Figure 3.6. 


\section{5\% 75\% I Range within 1.5IQR - Median Line $\square$ Mean • Outliers}

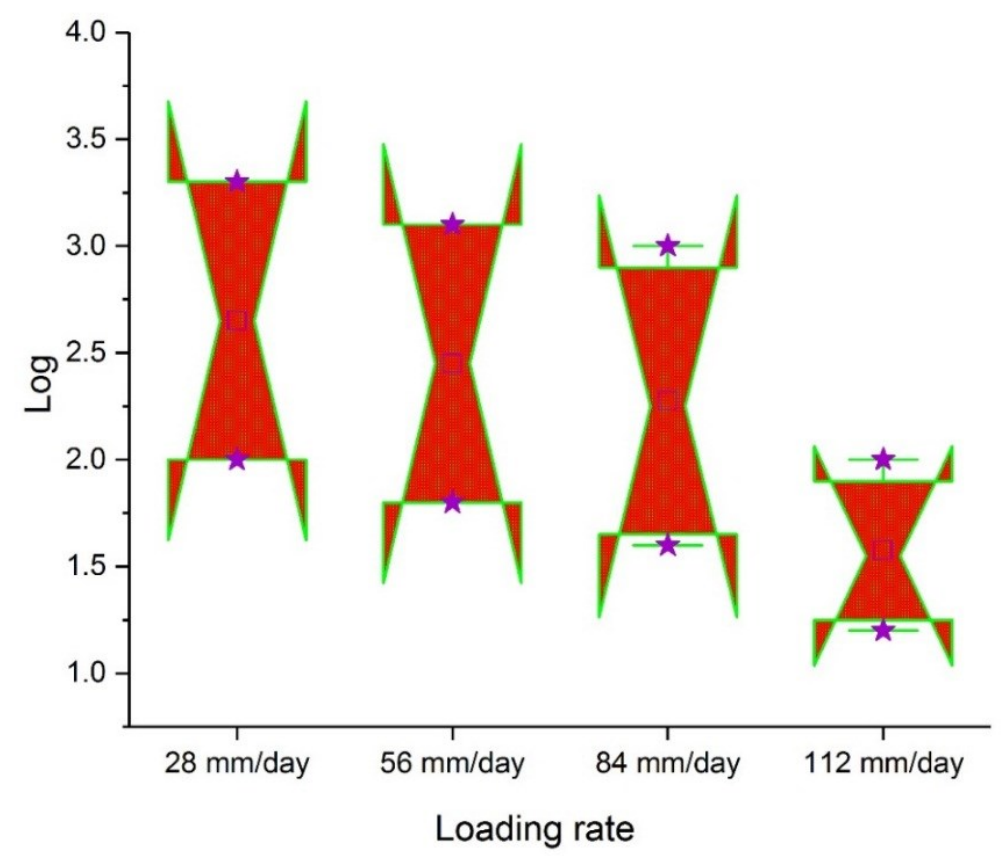

Figure 3.6 Reduction of FC at different HLRs

Log removal of FC increased from 0.08-2, 0.06-1.8, 0.04-1.6 and 0.02-1.2 for $28 \mathrm{~mm} / \mathrm{d}$, $56 \mathrm{~mm} / \mathrm{d}, 84 \mathrm{~mm} / \mathrm{d}$ and $112 \mathrm{~mm} / \mathrm{d}$ respectively during the first seven weeks. After $8^{\text {th }}$ week, a maximum of $3.3 \log$ reduction was achieved at $28 \mathrm{~mm} / \mathrm{d}$ while, $3.1 \log$ reduction, $2.9 \log$ reduction and $2 \log$ reduction was achieved for $56 \mathrm{~mm} / \mathrm{d}, 84 \mathrm{~mm} / \mathrm{d}$ and $112 \mathrm{~mm} / \mathrm{d}$ respectively.

Among the four wetland species: Cyperus papyrus, Cyperus alternifolius, Typha latifolia and Phragmites mauritianus; Cyperus alternifolius and Typha latifolia were effective in significant removal of Salmonella and E.coli above 98\% followed by Cyperus papyrus. The pathogen removal $\%$ of Phragmites mauritianus was least (Kipasika et al. 2016). The highest removal of $96 \%$ and $89 \%$ total coliforms and E.coli was reported in subsurface flow wetlands (Reinso et al. 2008). Domestic wastewater treatment with Cyperus papyrus attained $99.99 \%$ removal of fecal coliforms equivalent to $2 \log$ units (Mburu et al. 2008). Reduction of 1.28, 1.21 and $1.01 \mathrm{log}$ units of total coliform, fecal coliform and E.coli was attained in multilayered substrates of CWS without plantation (Latrach et al. 2015). 


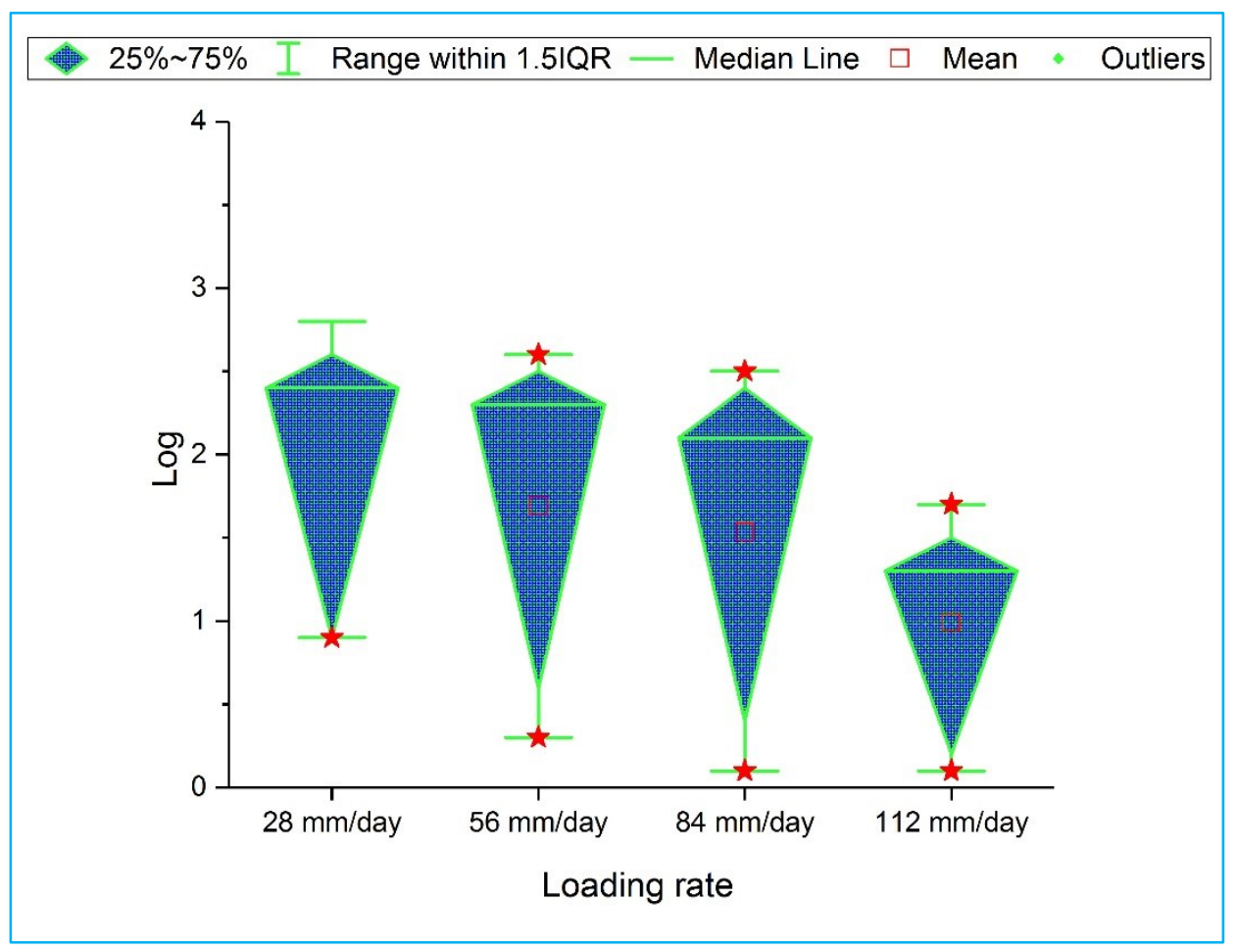

Figure 3.7 Reduction of E.coli at different HLRs

After $99.9 \%$ removal of E.coli, total coliforms and fecal coliforms, pathogens still persists in the effluent than the permissible limit of STP except membrane bioreactor and further research initiative is needed to achieve complete disinfection (Hendricks \& John pool 2012).

The range of E.coli in the inlet ranges from $5.9 \times 10^{4}$ to $37.8 \times 10^{5} \mathrm{MPN} / 100 \mathrm{~mL}$. The $\log$ reduction of E.coli in CWS at different HLR is presented in Figure 3.7. Log removal of E.coli increased from $0.8-1.9,0.3-1.4,0.1-1.6$ and $0.1-1.3$ for $28 \mathrm{~mm} / \mathrm{d}, 56 \mathrm{~mm} / \mathrm{d}, 84 \mathrm{~mm} / \mathrm{d}$ and $112 \mathrm{~mm} / \mathrm{d}$ respectively during the first seven weeks. After $8^{\text {th }}$ week a maximum of $2.8 \mathrm{log}$ reduction was achieved at $28 \mathrm{~mm} / \mathrm{d}$ while, 2.6.1 log reduction, $2.4 \log$ reduction and $1.7 \mathrm{log}$ reduction was achieved for $56 \mathrm{~mm} / \mathrm{d}, 84 \mathrm{~mm} / \mathrm{d}$ and $112 \mathrm{~mm} / \mathrm{d}$ respectively. The effectiveness of E.coli removal in CWS majorly depends on the filtering mechanism. Reduction of $4.7 \mathrm{log}$ of E.coli was reported in sand filtration (Seeger et al. 2016). Sand beds are capable of removing 1.2-2.7 log unit of total coliforms and 1.5-3.5 log unit of E.coli (Bohorquez et al. 2016). Fine media had an increased log reduction than coarse media (Albalawneh et al. 2016).

Typha latifolia in CWS potentially removed $96.8-99.7 \%$ of fecal coliforms throughout a period of 17 months (Smith et al. 2005). Karathanasis et al. (2003) reported more than 93\% removal of fecal coliforms in CWS planted with Typha latifolia. In hybrid CWS with Paspalidium flavidum 98.6\% removal of fecal coliform in domestic wastewater was reported by Sehar et al. (2013). The pathogen removal in CWS is not adequate and requires an additional treatment for disinfection. Maximum of $6 \log$ reduction is recommended by WHO (2006) for wastewater reuse in agriculture.

\subsubsection{Removal of TSS and TDS in VFCWS}

The fate of suspended organic matter under anaerobic condition in CWS is presented in Figure 3.8. The microbes involved in degradation of organic matter are discussed under the section: micro flora in CWS.

The concentration of TSS in the influent ranges from 300-360 mg/L. The results of TSS removal in CWS at different HLR and the concentration in inlet and outlet is presented in Figure 3.9. Results revealed maximum removal of $80-88 \%$ TSS with the discharge quality of $<50 \mathrm{mg} / \mathrm{L}$ at 84 $\mathrm{mm} / \mathrm{d}$ whereas, $70-75 \%, 75-80 \%$ and $78-83 \%$ removal was achieved for $56 \mathrm{~mm} / \mathrm{d}, 84 \mathrm{~mm} / \mathrm{d}$ and 112 $\mathrm{mm} / \mathrm{d}$ respectively. The respective concentration of TSS in the effluent at maximal removal \% was $45,40,35$ and $38 \mathrm{mg} / \mathrm{L}$ for $28 \mathrm{~mm} / \mathrm{d}, 56 \mathrm{~mm} / \mathrm{d}, 84 \mathrm{~mm} / \mathrm{d}$ and $112 \mathrm{~mm} / \mathrm{d}$ respectively. 


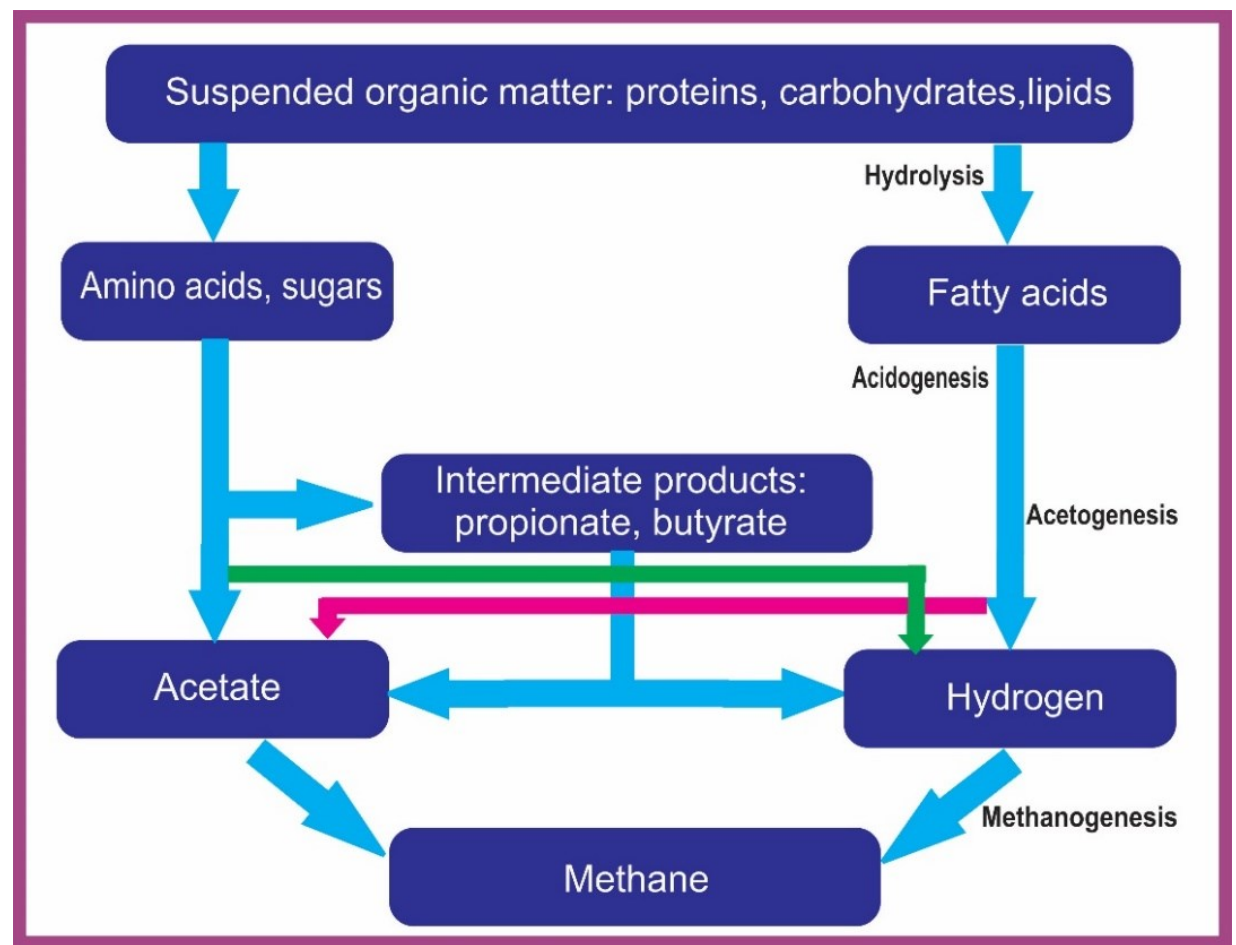

Figure 3.8 Fate of suspended organic matter under anaerobic condition in CWS

Removal of TSS in the system is majorly attributed by filtration and sedimentation. The organics in the sediments are further degraded by the microbes in the system. The lateral roots of Cyperus adds an additional impact in the mechanism of filtration. The root zone of plants contribute as filter media for highest removal of TSS (Chandrakanth et al. 2016).

VFCWS treating domestic wastewater with Phragmites australis is reported to remove 93.2\% (Gikas et al. 2007) and Typha latifolia $>88 \%$ of TSS (Karathanasis et al. 2003). HFCWS with Phragmites australis effectively removed TSS of $84.3 \%$ (Li et al. 2017) and kenaf 79\% (Albalawneh et al. 2016).

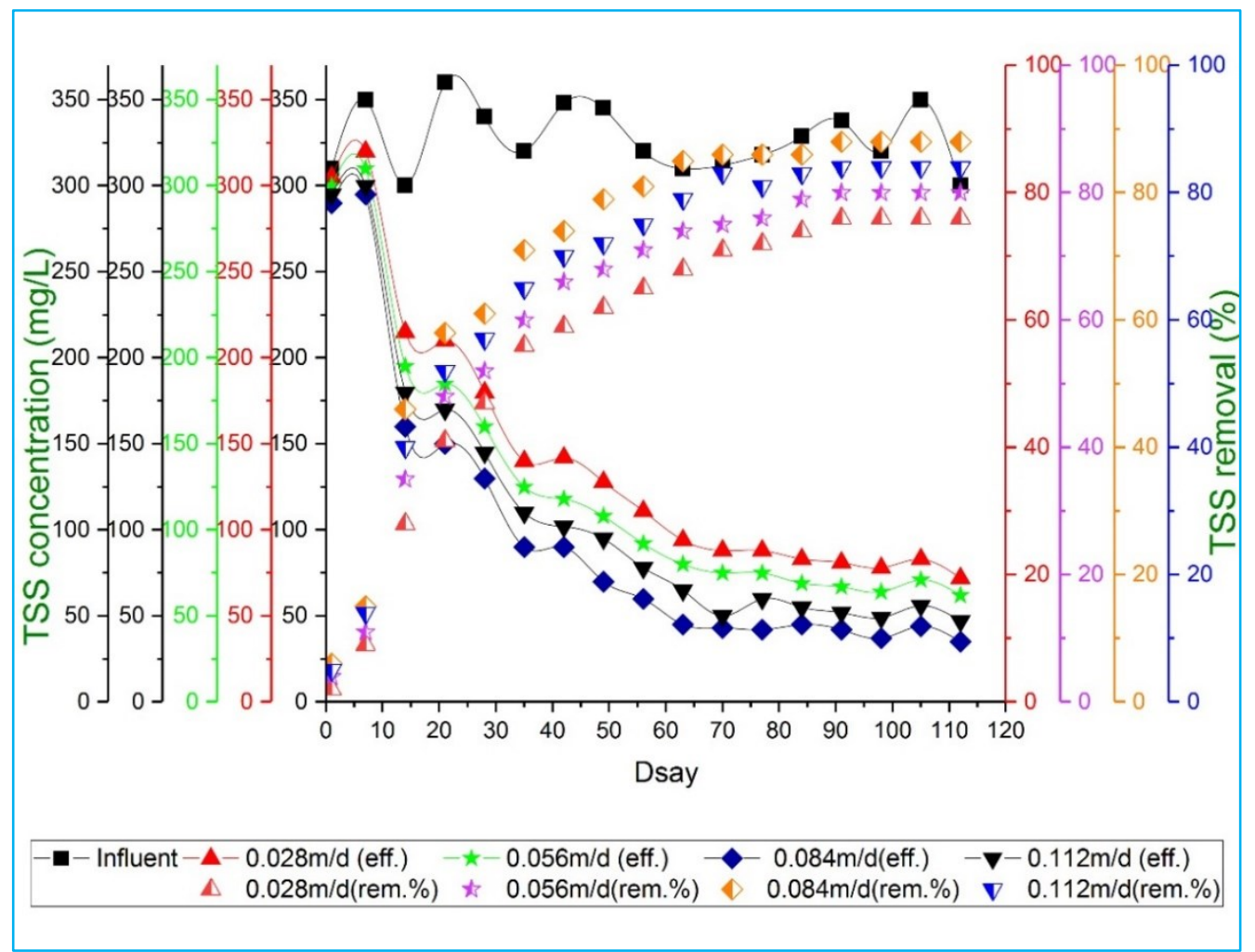

Figure 3.9 TSS Removal in VFCWS 
Manios et al. (2003) reported that among different substrates, gravel reed bed planted with Typha had the best removal of TSS more than $95 \%$ with effluent concentration of less than $10 \mathrm{mg} / \mathrm{L}$. About $95-97 \%$ of TSS removal throughout the year was achieved irrespective of season (Smith et al. 2006). Synergistic effect of Typha, Cyperus and Phragmites in CWS could remove 97.6\% of TSS (Nzengya \& Wishitemi 2001) while, Typha and Phragmites efficiently removed 96\% (Mirunalini et al. 2014). Eichornia crassipes efficiently removed $82 \%$ of TSS in sewage (Yadav et al. 2011).Integration of Cyperus papyrus and Phragmites mauritianus potentially removed $80.01 \%$ of TSS while Cyperus species alone could achieve only 79\% removal (Nzabuheraheza et al. 2012). Generally, TSS removal of $85 \%$ was achieved in CWS irrespective of the plant species.

The concentration of TDS in the influent ranges from $430-480 \mathrm{mg} / \mathrm{L}$. The results of TDS removal in CWS at different HLR is presented in Figure 3.10.

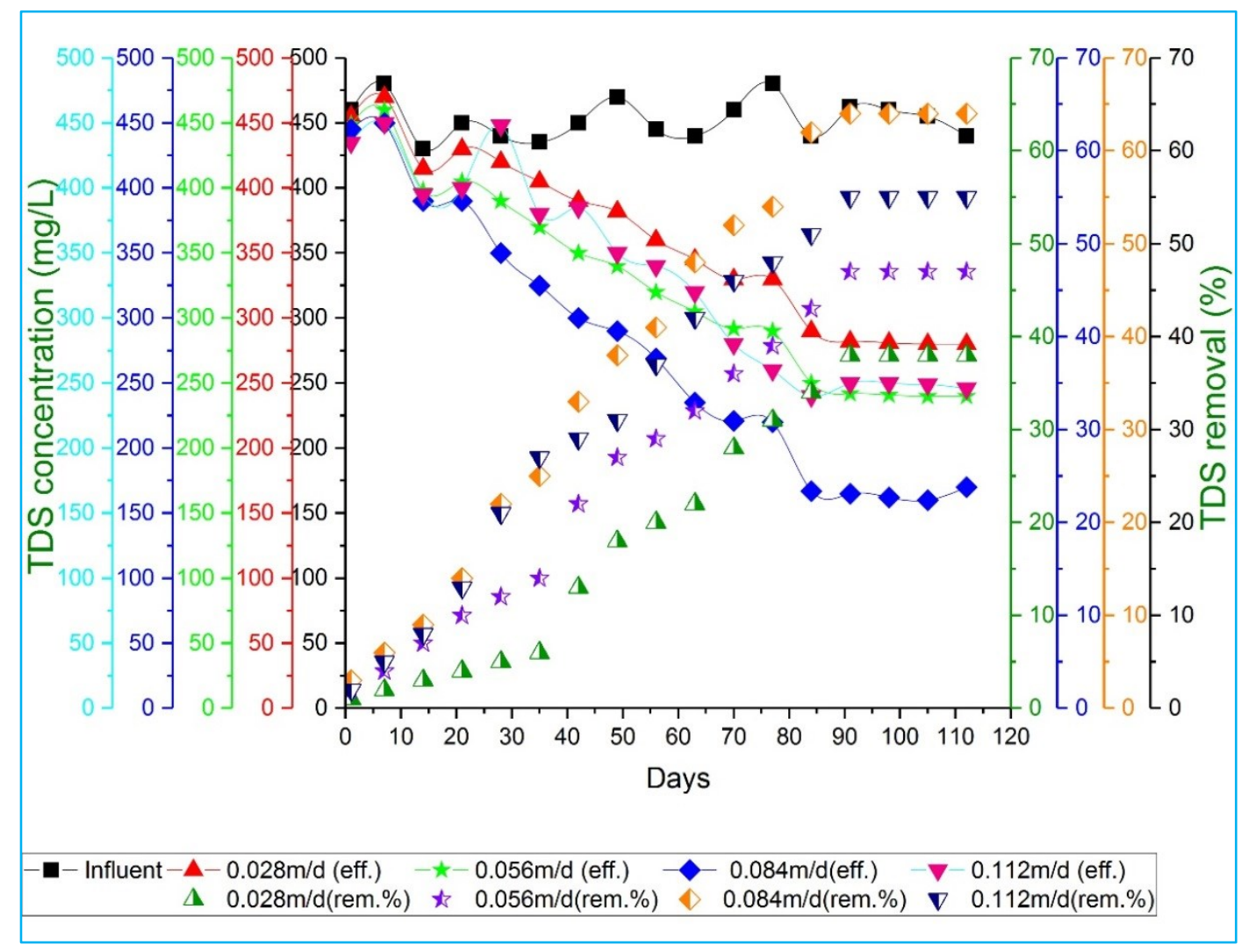

Figure 3.10 TDS Removal in VFCWS

Maximum removal of $60-64 \%$ was attained at $84 \mathrm{~mm} / \mathrm{d}$ and removal of $34-38 \%, 43-47 \%$ and $51-55 \%$ was achieved for $28 \mathrm{~mm} / \mathrm{d}, 56 \mathrm{~mm} / \mathrm{d}$ and $112 \mathrm{~mm} / \mathrm{d}$ respectively. The respective concentration of TDS in the effluent at maximal removal \% was 280, 240, 170 and $246 \mathrm{mg} / \mathrm{L}$ for 28 $\mathrm{mm} / \mathrm{d}, 56 \mathrm{~mm} / \mathrm{d}, 84 \mathrm{~mm} / \mathrm{d}$ and $112 \mathrm{~mm} / \mathrm{d}$ respectively. The prime mechanism of dissolved solids is via microbial degradation.

Integration of Cyperus papyrus and Phragmites mauritianus potentially removed $72.07 \%$ of TDS while Cyperus species alone could achieve only 71\% (Nzabuheraheza et al. 2012). In HFCWS $84 \%$ of TDS removal was reported when Phragmites was used (Andreo- Martinez et al. 2016). VFCWS treating domestic wastewater with Phragmites australis is reported to remove $57.34 \%$ of TDS (Sudarsan et al. 2015). Eichornia crassipes efficiently removed 71\% of TDS in sewage (Yadav et al. 2011).

\subsubsection{Removal of Heavy Metals in VFCWS}

The concentration of lead in the influent ranged from $0.156-0.263 \mathrm{mg} / \mathrm{L}$. With respect to the removal of heavy metals $\mathrm{Fe}$ and $\mathrm{Pb}$ in our study, the effluent collected from outlets at different HLR confined the limits of discharge. However, the removal \% varied at different HLR involved in the study. A maximum of $90-94 \%$ removal of lead was accomplished at $84 \mathrm{~mm} / \mathrm{d}$ confronting effluent 
standards as per CPCB (2005). Lead removal of $65-66 \%, 74-77 \%$ and $78-80 \%$ was achieved for 28 , 56 and $112 \mathrm{~mm} / \mathrm{d}$ respectively. The respective concentration of lead in the effluent at maximal removal \% was $0.062,0.042,0.011$ and $0.036 \mathrm{mg} / \mathrm{L}$ for $28 \mathrm{~mm} / \mathrm{d}, 56 \mathrm{~mm} / \mathrm{d}, 84 \mathrm{~mm} / \mathrm{d}$ and $112 \mathrm{~mm} / \mathrm{d}$ respectively. The influent and effluent concentration with lead removal efficiency at different HLR is presented in Figure 3.11. Efficient removal of heavy metals by biological treatment is achieved best at pH 8.8 (Rajasulochana \& Preethty 2016). The alkaline $\mathrm{pH}$ of the sewage might be one of the reason for efficient removal. The lateral roots of Cyperus play a major part in heavy metal uptake.

Metals may be retained in the sediments either in oxidized/ reduced soil conditions (Sinicrope et al. 1992). A study conducted on the comparison of three species of Cyperus: Cyperus alternifolius, Cyperus prolifer and Cyperus textilis for uptake and tolerance of heavy metals aluminium and iron revealed that, Cyperus alternifolius was the best fit for phytoremediation. However few reports are available about the genus Cyperus in heavy metal removal (Ayeni 2016).

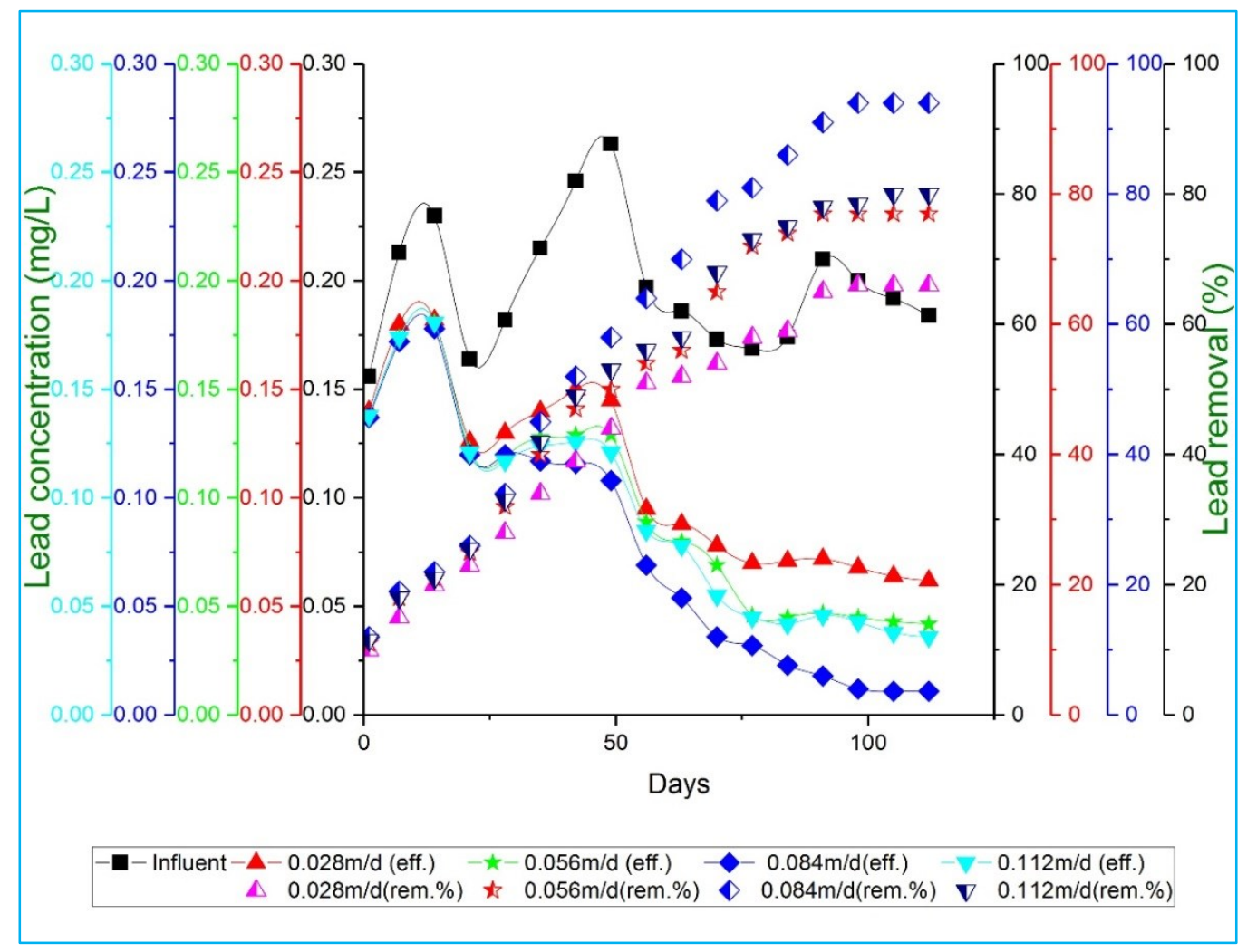

\section{Figure 3.11 Lead Removal in VFCWS}

Phragmites australis could efficiently remove $88 \%$ lead and $92 \%$ iron. Typha could proficiently remove $87 \%$ lead and $95 \%$ iron (Gikas et al. 2013). The removal of lead by substrates is influenced by the concentration of iron in the system (Ren et al. 2016). An average of $60.6 \%$ removal of lead was observed in HFCWS planted with Phragmites australis (Li et al. 2017).

The concentration of iron in the influent ranged from 3.28 to $5.82 \mathrm{mg} / \mathrm{L}$. A maximum of $82-85 \%$ removal was attained at $84 \mathrm{~mm} / \mathrm{d}$ confronting discharge quality. Iron removal of $70-72 \%$, $77-78 \%$ and $76-79 \%$ was achieved for $28 \mathrm{~mm} / \mathrm{d}, 56 \mathrm{~mm} / \mathrm{d}$ and $112 \mathrm{~mm} / \mathrm{d}$ respectively. The respective concentration of lead in the effluent at maximal removal \% was $1.5,1.2,0.8$ and $1.1 \mathrm{mg} / \mathrm{L}$ for 28 $\mathrm{mm} / \mathrm{d}, 56 \mathrm{~mm} / \mathrm{d}, 84 \mathrm{~mm} / \mathrm{d}$ and $112 \mathrm{~mm} / \mathrm{d}$ respectively. Heavy metals are removed as their bicarbonate due to bacterial production of bicarbonate alkalinity and as insoluble sulphide. The reduction of metals to non-mobile forms is achieved by microbial activity in wetlands and the reducing conditions are afforded by sulphate reducing bacteria. Iron and lead are precipitated into insoluble sulphides in CWS (Sheoran \& Sheoran 2006). The influent and effluent concentration with iron removal efficiency at different HLR is presented in Figure 3.12. 
Iron uptake by plants might be favoured as it is one of the critical component involved in many physiological process of plant: DNA synthesis, respiration, photosynthesis, mitochondrial and chloroplast metabolism. When iron enters the xylem, it complexes with citrate (Rout \& Sahoo 2015).

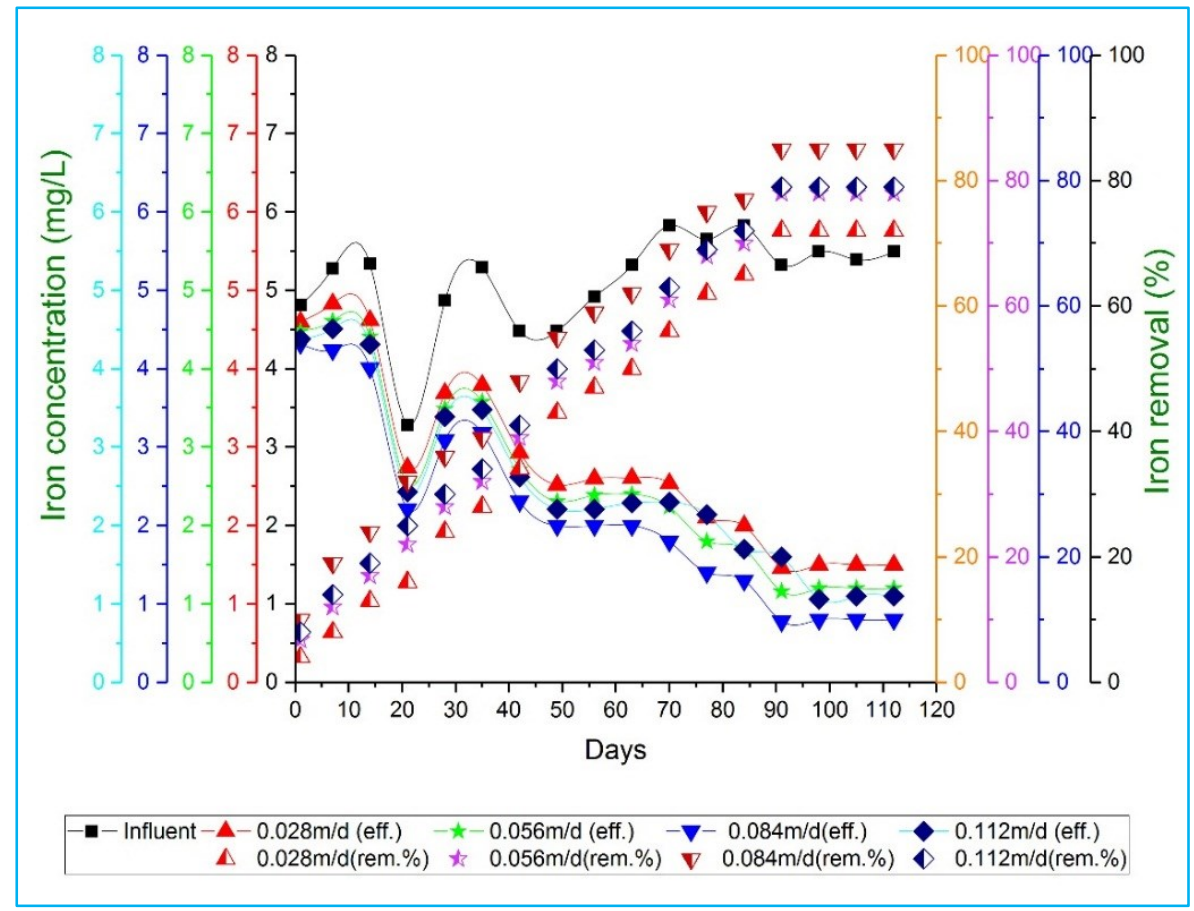

Figure 3.12 Iron Removal in VFCWS

Plant cell wall has cationic exchange sites named phytochelatins that detoxify and balance homeostasis of heavy metal uptake. Metal reduction can be tolerated in the body mass of plants without showing negative effects on its growth (Sheoran \& Sheoran 2006). Heavy metals present in wastewater are effectively removed by the wetland mesocosms at different hydroperiods (Sinicrope et al. 1992).

\section{Conclusion}

Among the diverse existing wastewater treatments schemes, CWS secures a peculiar place for its aesthetic value in addition to low cost maintenance. The optimal HLR for VFCWS planted with Cyperus alternifolius was $84 \mathrm{~mm} / \mathrm{d}(60 \mathrm{~L} / \mathrm{d})$ with discharge quality which met the standards of discharge for agriculture and inland water. Hence the effluent can be utilized either for irrigation or used for ground water recharge. Vegetation is the major factor contributing the removal of organics and nutrients. The dynamic role of microbes in removal of organics, nutrients and heavy metal removal is inevitable and secures a noteworthy place in CWS. CWS not only aids in treatment but also biodiversity thus favouring a successful ecological balance apart from sustainable treatment of sewage. A few clippings of visitors indicating biodiversity in CWS clicked at the time of sample collection is presented in Figure. 4.1. The different species such as caterpillar, grasshopper, snail etc were observed in the constructed wetland system indicating it as a clean green way in sewage treatment without affecting the ecosystem and biodiversity. 


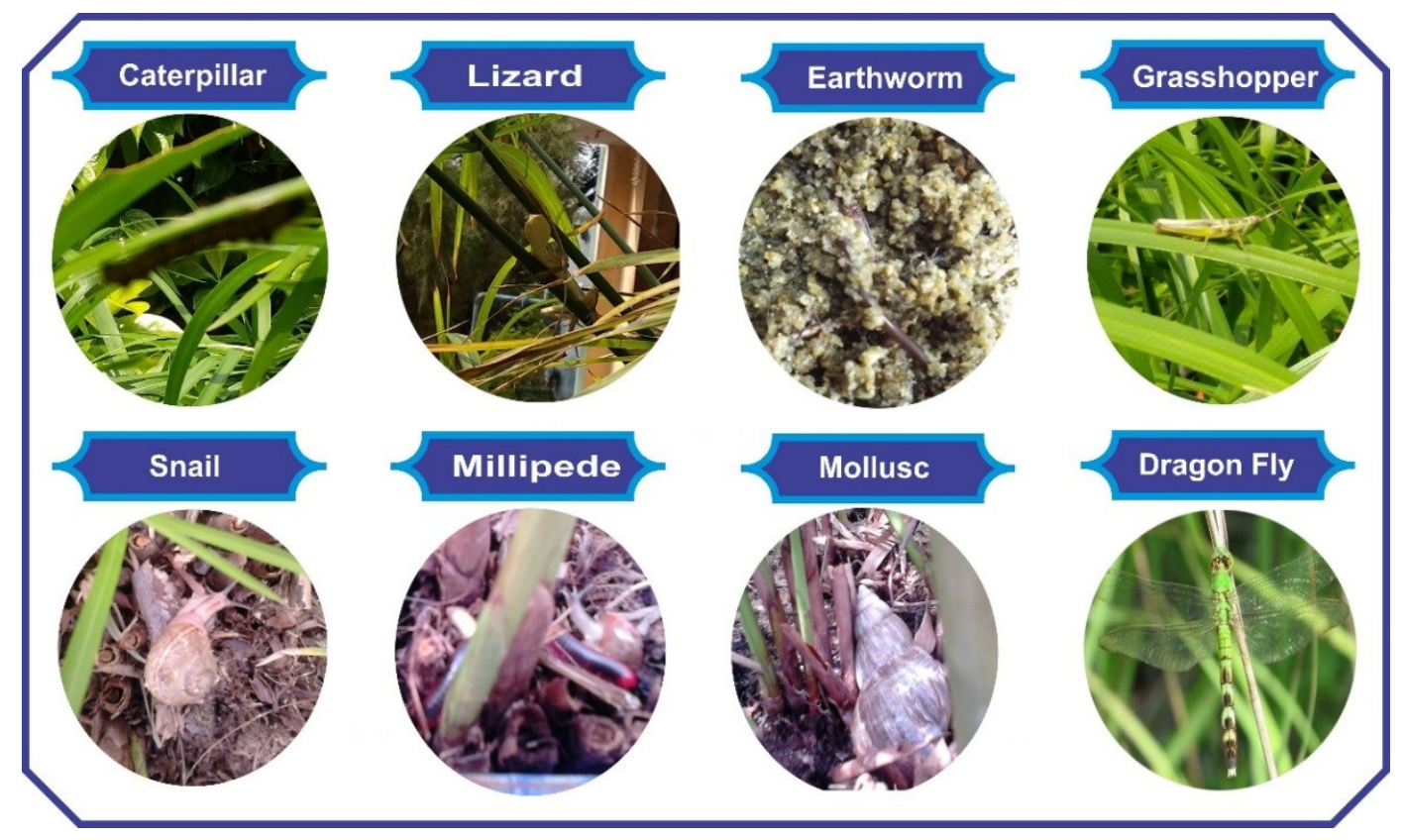

Figure 4.1 Visitors at CWS indicating biodiversity

In a nutshell it can be concluded that for tropical countries CWS is not only the evergreen technology that provides solution for wastewater treatment but the best for deterrence of exploitation of diversity. The harvested plants can be left decayed because the oxidation of the heavy metals were changed such that it remains less toxic. The findings related to this are continued in the further studies.

\section{Acknowledgement}

The author wish to thank UGC (University Grants Commission), New Delhi for financial support in persuading the research.

\section{References}

[1] Abdelhakeem, SG, Aboulroos, SA \& Kamel, MM 2016, 'Performance of a vertical subsurface flow constructed wetland under different operational conditions', Journal of Advanced Research, vol.7, no.5, pp. 803-814.

[2] Akratos, CS \& Tsihrintzis, VA, 2007, 'Effect of temperature, HRT, vegetation and porous media on removal efficiency of pilot scale horizontal subsurface flow constructed wetlands', Ecological Engineering, vol. 29, no. 2, pp. 173-191.

[3] Albalawneh, A, Chang, TK, Chou, CS \& Naoum, S 2016, 'Efficiency of horizontal sub-surface flow constructed wetland treatment system in an arid area', Water, vol.8, no.51, pp. 1-14.

[4] Andreo- Martinez, P, Garcia- Martinez \& Almela L 2016, 'Domestic wastewater depuration using a horizontal subsurface flow constructed wetland and theoretical surface optimization: A case study under dry Mediterranean climate' Water, vol.8, no.434, pp. 1-18.

[5] APHA (American public Health association) 2017, Standard methods for the examination of water and wastewater, $23^{\text {rd }}$ edition, Washington, D.C., Newyork, N.Y.

[6] Ayeni, OO 2016, Growth response within the genus Cyperus exposed to iron and aluminium in hydroponics, Thesis.

[7] Baloyi, C, Gumbo, JR \& Muzerengi, C 2014, 'Pollutants in sewage effluent and sludge and their impact on downstream water quality: a case study of Malamulele sewage plant, South Africa', WIT transactions on Ecology and the Environment, vol. 182, pp. 15-26. 
[8] Bilgrami, KS \& Kumar, S 1998, 'Bacterial contamination in water of the River Ganga and its risk to human health', International Journal of Environmental Health Research, vol.8, no.1, pp. 5-13.

[9] Bohorquez, E, Paredes, D \& Arias, CA 2016, 'Vertical flow constructed wetlands for domestic wastewater treatment under tropical conditions: effect of different design and operational parameters', Environmental Technology, vol.38, no.2, pp. 199-208.

[10] Central Pollution Control Board (CPCB) 2016, CPCB Bulletin, vol.1, Updated on Dec $6^{\text {th }} 2016$.

[11] Chandrakanth, G, Srimurali M, Vivek Vardhan, CM 2016, 'A study on domestic wastewater treatment by pilot-scale constructed wetlands', International Journal of Chemtech Research, vol.9, no.06, pp. 376-383.

[12] Chino, M, Moriyama, K, Saito, H \& Morn, T 1991, 'The amount of heavy metals derived from domestic sources in Japan', Water, Air and Soil Pollution, vol.57, no.1, pp. 829-837.

[13] Cresswell HP and Hamilton (2002) Particle Size Analysis. In: Soil Physical Measurement and Interpretation for Land Evaluation. (Eds. NJ McKenzie, HP Cresswell and KJ Coughlan) CSIRO Publishing: Collingwood, Victoria. pp 224-239.

[14] Ebrahimi, A, Taheri, E, Ehrampoush, MH, Nasiri, S, Jalali, F, Soltani, R \& Fatehizadeh, A 2013, 'Efficiency of constructed wetland with Cyperus alternifolius applied for municipal wastewater treatment', Journal of Environmental and Public Health, vol.2013, no.815962, pp. $1-5$.

[15] Gajewska, M \& Skrzypiec, K 2018, 'Kinetics of nitrogen removal processes in constructed wetlands', E3S Web of Conferences, vol.26, no.1, pp. 1-4.

[16] Gikas, GD, Akratos, CS \& Tsihrintzis, VA 2007, 'Performance monitoring of a vertical flow constructed wetland treating municipal wastewater', Global Nest Journal, vol.9, no.3, pp. 277 285.

[17] Gikas, P, Ranieri, E \& Tchobanoglous, G 2013, 'Removal of iron, chromium and lead from wastewater by horizontal subsurface flow constructed wetlands', Journal of Chemical Technology and Biotechnology, vol.88, no.10, doi:10.1002/jetb.4048.

[18] Gonzalez, PJ, Correia, C, Moura, I, Brondino, CD \& Moura, JJG 2006, 'Bacterial nitrate reductases: molecular and biological aspects of nitrate reduction- review article', Journal of Inorganic Chemistry, vol.100, pp. 1015-1023.

[19] Groeschke, M, Frommen, T, Winkler, A \& Schneider, M 2017, 'Sewage borne ammonium at a river bank filtration site in central Delhi, India: Simplified flow and reactive transport modeling to support decision- making about water management strategies', Geosciences, vol.7, no.48, pp. 1-16.

[20] Karathanasis, AD, Potter, CL \& Coyne, MS 2003, 'Vegetation effects on fecal bacteria, BOD and suspended solid removal in constructed wetlands treating domestic water', Ecological Engineering, vol.20, no.2, pp. 157-169.

[21] Kipasika, HJ, Buza, J, Smith, WA \& Njau, KN 2016, 'Removal capacity of faecal pathogens from wastewater by four wetland vegetation: Typha latifolia, Cyperus papyrus, Cyperus alternifolius and Phragmites mauritianus', African Journal of Microbiology Research, vol.10, no.19, pp. 654-661.

[22] Klomjek, P 2016, 'Swine wastewater treatment using vertical subsurface flow constructed wetland planted with Napier grass', Sustainable Environmental Research, vol.26, no.5, pp. 217 223.

[23] Kumar, JLG, Zhao, YQ \& Babatunde, AO 2011, 'Process-based modelling of phosphorus removal in a novel constructed wetland system using dewatered alum sludge as substrate', Water Science and Technology, vol.64, no.3, pp. 774-780. 
[24] Kyambadde, J, Kansiime, F \& Dalhammar, G 2005, 'Nitrogen and phosphorus removal in substrate -free pilot constructed wetlands with horizontal surface flow in Uganda', Water, Air and Soil pollution, vol. 165, no. 1-4, pp. 37-59.

[25] Lamastra, L, Balderacchi, M \& Trevisan, M 2016, 'Inclusion of emerging organic contaminants in ground water monitoring plans', Methods X, vol.25, no.3, pp. 459-476.

[26] Latrach, L, Masunaga, T, Ouazzani, N, Hejjaj, A, Mahi, M \& Mandi, L 2015, 'Removal of bacterial indicators and pathogens from domestic wastewater by the multi-soil-layering (MSL) system', Soil Science and Plant Nutrition, vol.61, no.2, pp. 337-346.

[27] Lee, DJ, Kang, SW, Park, JH, Kim, SH, Choi, IW, Hwang, TH, Lim, BJ, Jung, SJ, Park, HN, Cho, JS \& Seo, D.C 2015, 'Enhancement of nutrient removal in hybrid constructed wetland utilizing an electric fan air blower with renewable energy of solar and wind power', Journal of Chemistry, vol.2015, no.813827, pp. 1-8.

[28] Li, YC, Zhang, DQ \& Wang, M 2017, 'Performance evaluation of a full-scale constructed wetland for treating stormwater runoff', Clean-soil, Air Water, vol.45, no.11, pp. 1-11.

[29] Luederitz, V, Eckert, E, Lange-Weber, M, Lange, A \& Gersberg, RM 2001, 'Nutrient removal efficiency and resource economics of vertical flow and horizontal flow constructed wetlands', Ecological Engineering, vol.18, pp. 157-171.

[30] Manios, T, Stentiford, I \& Millner, P 2003, 'Removal of total suspended solids from wastewater in constructed horizontal flow subsurface wetlands', Journal of Environmental Science and Health, vol.A38, no.6, pp. 1073-1085.

[31] Mburu, N, Thumbi, GM \& Mayabi, AO 2008, Removal of bacterial pathogens from domestic wastewater in a tropical subsurface horizontal flow constructed wetland, Proceedings of Taal 2007: The $12^{\text {th }}$ world lake conference. pp. 1010-1015.

[32] Mesquita, MC, Albuquerque, A, Amaral, L \& Nogueira, R 2017, 'Seasonal variation of nutrient removal in a full-scale horizontal constructed wetland', Energy Procedia, vol.136, pp. 225-232.

[33] Metcalf \& Eddy 2003, Wastewater engineering: treatment, disposal and reuse, McGraw Hill, New York.

[34] Mirunalini, V, Sudarsan, JS, Deeptha, VT \& Paramaguru, T 2014, 'Role of integrated constructed wetland for wastewater treatment', Asian Journal of Applied Sciences, vol.7, pp. 448-452.

[35] Naden, P, Bell, V, Carnell, E, Tomlinson, S, Dragosits, U, Chaplo, J, May, L \& Tipping, E 2016, 'Nutrient fluxes from domestic wastewater: A national- scale historical perspective for the UK 1800-2010', Science of the Total Environment, vol.572, no.1, pp. 1471-1484

[36] Nzabuheraheza, FD, Katima, JHY, Njau, KN Kayombo \& Niyigena, NA 2012, 'Wastewater treatment for pollution control', Rwanda Journal of Health Sciences, vol.1,no.1,pp. 1-7.

[37] Nzengya, DM \& Wishitemi, BEL 2001, 'The performance of constructed wetlands for wastewater treatment: a case study of splash wetland in Nairobi Kenya', Hydrological Process, vol.15, pp. 3239-3247.

[38] Oghenerobor Benjamin Akpor1, Gladys Onolunose Ohiobor, Tomilola Debby Olaolu,2014, 'Heavy metal pollutants in wastewater effluents: Sources, effects and remediation' Advances in Bioscience and Bioengineering, vol. 2(4). pp 37-43.

[39] Prajapati, M, Van Bruggen, JJA, Dalu, T \& Malla, R 2017, 'Assessing the effectiveness of pollutant removal by macrophytes in a floating wetland for wastewater treatment', Applied Water Science, vol.7, no.8, pp. 4801-4809.

[40] Qomariyah, S, Ramelan, AH, Sobriyah \& Setyono, P 2017, 'Use of macrophyte plants, sand and gravel materials in constructed wetlands for grey water treatment',IOP conference series: Materials Science and Engineering, vol.176, pp. 1-6. 
[41] Rajasulochana, P \& Preethy, V 2016, 'Comparison on efficiency of various techniques in treatment of waste and sewage water - A comprehensive review', Resource- Efficient Technologies, vol.2, no.4, pp. 175-184.

[42] Ramakrishna Rao, S, Bala Prasad, S, Raja Sekhar, PS \& Rahiman, S.A 2013, 'Performance studies on wastewater treatment efficiency of an artificial wetland', Journal of Environmental Engineering and Technology, vol.2, no.3, pp. 40-45.

[43] Reinso, R, Torres, L.A \& Becares, E 2008, 'Efficiency of natural systems for removal of bacteria and pathogenic parasites from wastewater' Science of the Total Environment, , vol.395, pp. $80-85$.

[44] Rout, GR \& Sahoo, S 2015 'Role of iron in plant growth and metabolism', Reviews in Agricultural Science, vol.3, pp. 1-24.

[45] Schriewer, A, Odagiri, M, Wuertz, S, Misra PR, Panigrahi, P, Clasen, T \& Jenkins, M.W 2015, 'Human and animal fecal contamination of community water resources, stored drinking water and hands in rural India measured with validated microbial source tracking assays', The American Medicine of Tropical Medicine and Hygiene, vol.93, no.3, pp. 509-516.

[46] Seeger, EM, Braeckevelt, M, Reiche, N, Muller, JA \& Kastner, M 2016, 'Removal of pathogen indicators from secondary effluent using slow sand filtration: optimization approaches', Ecological Engineering, vol.95, pp. 635-644.

[47] Sehar, S, Aamir, R, Naz, I, Ali, N \& Ahmed, S 2013. 'Reduction of contaminants (Physical, chemical and microbial) in domestic wastewater through hybrid constructed wetland', ISRN Microbiology, vol.2013, no. 350260, pp. 1-9.

[48] Shahi, DH, Eslami, H, Ehrampoosh, MH, Ebrahimi, A, Ghaneian, MT, Ayatollah, S \& Mozayan, MR 2013, 'Comparing the efficiency of Cyperus alternifolius and Phragmites australis in municipal wastewater treatment by subsurface constructed wetland', Pakistan Journal of Biological Science, vol. 16, no.8, pp. 379-384.

[49] Sharma, P \& Gupta, S 2014, ' Study of amount of oxygen (BOD, OD, COD) in water and their effect on fishes', American International Journal of Research in Formal, Applied \& Natural Sciences, vol.7, no.1, pp. 53-58.

[50] Sheoran, AS \& Sheoran, V 2006, 'Heavy metal removal mechanism of acid mine drainage in wetlands: A critical review', Minerals Engineering, vol.19, pp. 105-116.

[51] Shrestha, Arun Basnet, Nabin Bohora, C and Khadka, P. 2017. 'Variation of Electrical Conductivity of the Different Sources of Water with Temperature and Concentration of Electrolyte Solution NaCl'.

[52] Sinicrope, TL, Langis, R \& Gersberg, RM 1992, 'Metal removal by wetland mesocosms subjected to different hydroperiods', Ecological Engineering, vol.1, pp. 309-322.

[53] Smith, E, Gordon, R, Madani, A \& Stratton, G 2005, 'Pathogen removal by agricultural constructed wetlands in cold climates', Journal of Environmental Informatics, vol.6, no.1, pp. 46-50.

[54] Smith, E, Gordon, R, Madani, A \& Stratton, G 2006, 'Year-round treatment of dairy wastewater by constructed wetlands in Atlantic Canada', Wetlands, vol. 26, no.2, pp. 349-357.

[55] Sonune, NA, Mungal, NA \& Kamble, SP 2015, 'Study of physic-chemical characterestics of domestic wastewater in Vishnupuri, Nanded, India', International Journal of Current Microbiology and Applied Sciences, vol.4, no.1. pp. 533-536.

[56] Stefanakis, AI \& Tsihrintzis, VA 2012, 'Effects of loading, resting period, temperature, porous media, vegetation and aeration on performance of pilot scale vertical flow constructed wetlands', Chemical Engineering Journal, vol.181, no.182, pp. 416-430. 
[57] Sudarsan, JS, Lizbeth Roy, R, Baskar, G, Deeptha, VT \& Nithiyanantham, S 2015, 'Domestic wastewater treatment performance using constructed wetland', Sustainable Water Resources Management, vol.1, no.2, pp. 89-96.

[58] Times of India, 2015, Available from < http:/timesofindia. indiatimes.com/home/ environment/pollution/ 37000-million-litres-of-sewageflows-into-rivers-daily-Report/ articleshow/ 46657415.cms> Retrieved on March 23, 2015

[59] Tole, MP, Khisa, K, Anyango, S \& Mwangi, SW 2014, 'The efficacy of a tropical constructed wetland for treating wastewater during the wet season: The Kenyan experience', Journal of Environment and Earth Science, vol.4, no.15, pp. 66-73.

[60] Trang, NTD, Konneup, D, Schierup, HH, Chiem, NH, Tuan, LA \& Brix, H 2010, 'Kinetics of pollutant removal from domestic wastewater in a tropical horizontal subsurface flow constructed wetland system: Effects of hydraulic loading rate', Ecological Engineering, vol.36, no.4, pp. 527-535.

[61] U.S. Geological Survey, 2002, Concepts for national assessment of water availability and use: U.S. Geological Survey Circular 1223, p.34.

[62] Usharani \& Vasudevan, N, 2014, 'Impact of heavy metal toxicity and constructed wetland system as a tool in remediation', Archives of Environmental and Occupational Health, vol. 71, no. 2, pp. 102-110.

[63] Uwidia, IE \& Ukulu, HS 2013, 'Studies on electrical conductivity and total dissolved solids concentration in raw domestic wastewater obtained from an estate in Warri, Nigeria', Greener Journal of Physical Sciences, vol. 3, no.3, pp. 110-114.

[64] Wen,Y, Schoups, G \& Nick van de Giesen 2017, 'Organic pollution of rivers: Combined threats of urbanization, livestock farming and global climate change', Science Report, vol.7, no. 43289 , pp. 1-9.

[65] WHO 2006, Guidelines for the safe use of wastewater, excreta and greywater, Geneva, Switzerland.

[66] Yadav, SB, Jadhav, AS, Chonde, SG \& Raut, PD 2011, 'Performance of surface flow constructed wetland system by using Eichhornia crassipes for wastewater treatment in an institutional complex', Universal Journal of Environmental Research and Technology, vol.1, no.4, pp. 435-441.

[67] Yang, XJ, Tong, YM, Song, Y Qi, WK, Li, YY \& Guo, YL 2017, 'Domestic sewage and secondary effluent treatment using vertical submerged biological filter', IOP conference series: Earth and Environmental Science, vol.82, pp. 1-13. 